\title{
"MEDICAL ADVERSITY INSURANCE"- HAS ITS TIME COME?
}

\author{
Clark C. Havighurst*
}

In 1972, prior to the onset of the recent crisis in unedical malpractice insurance and the resulting widespread reappraisal of patients' legal rights and malpractice remedies, this writer participated in the formulation of a blueprint for "medical adversity insurance" (MAI), which was published as "a no-fault approach to medical malpractice and quality assurance." The MAI proposal was not a finished product, however, and it was not ready for serious legislative or professional consideration when the current problems arose and made the field suddenly fertile for substantive and procedural change. Indeed, it was presented less as a proposal for immediate adoption than as a theoretically sound model for further study and as a conceptual benchmark for evaluating both the fault system and existing quality-assurance mecl1anisms. Now, however, MAI has been given enough additional substance to qualify it for policy makers' attention.

The original MAI proposal was highly specific about the scheme's mechanics but sketchy about the coverage of the no-fault insurance which it contemplated that providers would purchase for the benefit of their patients. The emphasis on mechanical details in the original presentation no doubt obscured the essentials of the MAI idea, naniely (1) advance specification of a limited list of automatically compensable events, carefully drawn up by medical experts under some form of public supervision, and (2) design of the insurance scheme

* Professor of Law and Director, Program on Legal Issues in Health Care, Duke University. Work on this Article was supported by grant number HS01539 from the National Center for Health Services Research, U.S. Department of Health, Education and Welfare. Sue Rankin, Class of 1978, Duke University School of Law, assisted ably in the research, particularly in developing the tentative list of coinpensable events included in Part III.

THE FOLLOWING CITATIONS WILL BE USED IN THIS ARTICLE:

U.S. Dep'T of Health, Education and Welfare, Report of the Secretary's Commission on Medical Malpractice (1973) thereinafter cited as Medical MalpracTICE REPORT];

Havighurst \& Tancredi, "Medical Adversity Insurance"-A No-Fault Approach to Medical Malpractice and Quality Assurance, 51 Milank Memorial Fund Q. 125 (1973), reprinted in 613 INs. L.J. 69 (1974) thereinafter cited as Havighurst \& Tancredi, with page references to both sources].

1. Havighurst \& Tancredi. 
to keep providers in some measure financially accountable for the results of treatment in order to preserve and strengthen their incentives to avoid medical accidents and obtain better medical results. This Article concentrates on these essentials, attempting to be more specific about MAI's coverage, without reiterating or debating the compensation scheme's details. ${ }^{2}$ It also attempts to place the MAI proposal in the perspective of the on-going debate concerning the law of medical malpractice and the quality of medical care. ${ }^{3}$

\section{The FaUlt SYSTEM DisCREDITED}

\section{A. The Standard Arguments Against the Fault System}

The arguments for scrapping the fault system as the vehicle for dealing with medical injuries are quite persuasive. Indeed, even the conventional wisdom bears scrutiny rather well. The most frequently noted adverse consequences of the system as it is currently structured and administered may be listed as follows:

(1) the very high legal and administrative costs involved in claims processing and fault-finding; ${ }^{4}$

(2) the psychic and time costs to physicians occasioned by charges of professional negligence and by the litigation process used to evaluate such charges;

2. Under the original proposal, no-fault insurance would indemnify all medical expenses and all wage losses, subject to a minimum and maximum per week. Id. at 128, 71-72. It was suggested that some allowance might be made for severe pain and suffering on the basis of a formula rather than attempting to individualize such damages or ignoring them altogether. Id. at 128-29, 72. (On the proposed treatment of collateral sources, see text accompanying notes 110-12 infra.) Discovery of claims would be assured by requiring providers, as a condition of relief from malpractice claims, to disclose the existence of claims against an MAI fund. Id. at 130,73. Although it was suggested that policies not be cancellable, id. at 131,74 , it now seems unnecessary to make this an explicit requirement. Subrogation of the insurer to claims against such third parties as drug manufacturers and blood banks was contemplated as a means of strengthening the incentives of other actors in the system. Id. at 141, 81 .

3. Any advocate of policy change cannot be altogether comfortable when his argument is based almost exclusively on theory. Yet the potential complexity of MAI is sucl that only physicians can translate the concept into practical terms and prepare the plan for definitive assessment. Thus, this Article can only stress the rather powerful logic behind MAI and urge intensive investigation of its practical merit. Most importantly, it argues for evaluation of MAI on its own terms rather than under some other premise, and much of the discussion is devoted to examining the premises of participants in the inalpractice/quality-of-care debate.

4. See Steves, A Proposal to Improve the Cost to Benefit Relationships in the Medical Professional Liability Insurance System, 1975 DukE L.J. 1305. 
(3) the antagonisms unleashed, not only between doctors and patients but also between doctors and lawyers-or, more importantly, between doctors and the law itself, which physicians find arbitrary, incapable of drawing realistic distinctions, and responsive only to emotion and the crasser human instincts;

(4) "defensive" medical practice, defined as either (a) the use of diagnostic and other resources primarily for the purpose of protecting the physician against a successful malpractice claim rather than the patient against an adverse medical result or (b) the refusal to provide needed care or to adopt desirable new methods out of a concern that exposure to liability would be increased; 5 and

(5) the haphazard incidence of claims, which seem, like lightning, to strike largely at random, ${ }^{b}$ suggesting that $(a)$ many injuries go uncompensated, $(b)$ a vast amount of negligence goes unpoliced, and $(c)$ due process and the established legal inerit of a malpractice claim are insufficient guarantees, in view of the system's failure to treat all like things similarly, of the fairness of a judgment against an individual provider. ${ }^{7}$

Any benefits of the fault system whicl could offset the foregoimg disadvantages must be found in improvements in the quality of care that are stimulated by provider apprehensions about potential claims and liability. But, even if potential tort liability does perform a substantial quality-assurance function in the health care system, ${ }^{8}$ the costs

5. See, e.g., Bernzweig, Defensive Medicine, in Medical Malpractice Report Appendix 38; Hershey, The Defensive Practice of Medicine, Myth or Reality?, 50 MILBANK Memorial Fund Q. 69 (1972); Project, The Medical Malpractice Threat: A Study of Defensive Medicine, 1971 Duke L.J. 939-48; Address by Potchen, Twine \& Roberts, A Dynamic Systems Analysis of Defensive Medicine, Medical Malpractice Crisis Conference (U. of Md. School of Law, Nov. 21-22, 1975).

6. See Medical MAlPRACTICe Report 23; Peterson, Consumers Knowledge of and Attitudes Toward Medical Malpractice, in Medical Malpractice RePort Appendix 658, 665-93 (survey indicated many people had had "negative medical care experiences" without pursuing legal remedies); Brook, Brutoco \& Williams, The Relationship Between Medical Malpractice and Quality of Care, 1975 Duke LJ. 1197.

7. Physicians are particularly disturbed that claims appear to be occasioned less by variations in the technical quality of the care received than by such factors as the patient's personality and circumstances, the doctor's "bedside manner," the lawyer's interest in the claim, and chance disclosure of the existence of actionable negligence. See also text accompanying note 13 infra. The unscientific character of both the fact-finding process and the means of establishing the legal standard of care also contribute to perceptions of unfairness. See, e.g., Child, Lawyers, Doctors and Medical Malpractice: $A$ Surgeon Reacts, in MEDICAL MaLPRACTICE 43 (Shapiro, Steingold \& Needham eds. 1965).

8. There is substantial doubt about whether the hazard of malpractice claims con- 
of the current system's dysfunctional aspects are still so great as to compel attention to the possibility that the objectives sought could be achieved more cheaply or more effectively by other means.

The legislative deliberations precipitated by the recent malpractice crisis have not focused extensively on the possibility of a new departure. $^{9}$ Instead, the legislatures have been primarily concerned with shoring up the fault system, the insurance component of which was rapidly breaking down. ${ }^{10}$ In attempting to make insurable a set of risks which was becoming uninsurable, policy makers initially confined themselves to addressing the current system's defects, and only recently has attention been directed to the possibility of eliminating or de-emphasizing the fault factor in compensating for injuries. ${ }^{11}$ As one proposal for doing this, the MAI scheme also calls attention to the need either to maintain and perhaps strengthen the quality-assurance function of the injury-compensation system or to replace it with something at least equally effective. The MAI proposal should be helpful to ob-

tributes to improving the quality of: care. See Brook, Brutoco \& Williams, supra note 6, at 1220; Ball, PSRO, Malpractice Litigation, and Defensive Medicine, Medical Malpractice Crisis Conference (U. of Md. School of Law, Nov. 21-22, 1975). The possibility renains, however, that doctors' responses to the malpractice threat, including the phenomenon of defensive medicine, see text accompanying note 5 supra, contribute to better technical care than would be obtained if there were no sanctions for poor-quality care other than professional sanctions.

Another type of qualitative benefit may flow from physicians' perception that lawsuits are less likely to be initiated if the patient has not been personally offended during treatment. See Pabst, Comments on Medical Opinion Survey of Physicians' Attitudes on Medical Malpractice, in Medrcal Malpractice RePort Appendix 83, 84 (citing "poor communications" as the chief cause of the malpractice problem); Mechanic, Some Social Aspects of the Medical Malpractice Dilemma, 1975 DUKE L.J. 1179; Peterson, supra note 6. This may lead the physician to be more respectful of the patient's feelings, cultivating "bedside manner" as a means of avoiding lawsuits. Consumer groups and others have been hesitant to see patients' malpractice rights curtailed because of the lack of other means of holding providers accountable for the care provided. E.g., Wolfe, The Real Victim, Trial 26 (May/June 1975) ("Thus far, unfortunately, malpractice bitigation has clearly been the only form of protest in which the consumer lias had any reasonable chance at redress for grievances."). See also Thompson, Lupton \& Feldesman, Patient Grievance Mechanisms in Health Care Institutions, in Mrdical Malpractice REPORT Appendix 758. On MAI's inpact on this problem, see note 49 infra.

9. While radical, the Kennedy-Inouye no-fault bill, S. 215, 94th Cong., 1st Sess. (1975), was offered primarily for discussion purposes. See text accompanying notes 31-33 infra.

10. See Comment, An Analysis of State Legislative Responses to the Medical Malpractice Crisis, 1975 Duke L.J. 1417.

11. These possibilities lave been actively considered by the following, among others: National Conference on Medical Malpractice; Conference on the Medical Malpractice Crisis (U. of Md. School of Law, Nov. 21-22, 1975); ABA Commission on Medical Professional Liability; American Insurance Association All Industry Committee; and New York Special Advisory Panel on Medical Malpractice. See also note 9 supra. 
servers in identifying both the theoretical issues and the practical problems in designing acceptable compensation and quality-assurance mechanisins.

\section{B. Outcome Assessment Versus Process Standards}

The MAI scheme also points up some additional arguments, inore fundanental than the foregoing pragmatic ones, which can be advanced against continued reliance on the fault system. Thus, it reflects the attention which reformers in the liealth field have recently focused on the advantages of assessing the quality of medical care on the basis of actual outcomes-that is, in terms of resulting patient health-rather than on the basis of "process"- that is, the individual steps actually taken in treating the patient. ${ }^{22}$ Although inalpractice claims occur only where there has been a bad outcome, the fault system is in no other respect outcoine-oriented. For one thing, only a very small proportion of unsatisfactory outcomes produce claims, and fortuitous factors-for exaniple, doctor or patient personality traits, the degree to which the patient's hardship is mitigated by collateral sources of financial protection, and the patient's possible ignorance that negligence rather than bad luck accounted for his injury-are perhaps more important determinants of claims imitiation than a bad outcome itself. ${ }^{13} \mathrm{~A}$ bad outcome is therefore by no means a sufficient condition for a malpractice lawsuit, though it is obviously a necessary one. It may nevertheless still be true that the malpractice suit is the only appreciable external clieck on the quality of outcomes currently operating in the health care system. ${ }^{14}$

12. See, e.g., A. Cochrane, EFfectiveness aNd EFFICIENCY-RANDOM RgFleCtions on Health Services (1972); P. Ellwood, P. O'Donoghue, W. McClure et al., Assuring the Quality of Health Care (1973); Williamson, Outcomes of Health Care: Key to Health Improvement, in Methodology of Identifying, Mgasurino and Evaluating Outcomes of Health Service Programs, Systems, and Subsystems 75 (C. Hopkins ed. 1970); Brook \& Appel, Quality of Care Assessment: Choosing a Method for Peer Review, 285 NEw ENG. J. MED. 1323 (1973); Ball, supra note 8, at 11-16.

13. See notes 6-7 supra and accompanying text.

14. See Carlson, Health Manpower Licensing and Emerging Institutional Responsibility for the Quality of Care, 35 LAW \& CoNTEMP. PROB. 848, 859-62 (1970). Carlson, however, appears to regard malpractice claims as more of a check on outcomes than they are in fact, and neglects to classify hospital tissue review committees as another outcome-oriented control. More recently, Professional Standards Review Organizations (PSROs) have been formed for the purpose of regulating the quality of care with some expectation that they will engage in outcome assessment and studies of cost-effectiveness. 42 U.S.C. \$ 1320c (Supp. III, 1973). See Havighurst \& Blumstein, Coping With Quality/Cost Trade-offs in Medical Care: The Role of PSROs, 70 Nw. U.L. REv. 6 (1975); Ball, supra note 8, at 38. 
The legal standard of care employed under the fault system to judge provider negligence tends to focus attention on process rather than on outcome. Because liability is seldom automatic, ${ }^{15}$ but depends on a showing that the doctor departed from accepted practice or omitted some customary diagnostic or therapeutic measure, physicians are compelled to do what other doctors do, and they depart from common practice only at their peril. ${ }^{16}$ Certain kinds of "defensive" medicme reflect the effort of many physicians to reduce their legal exposure by erring on the side of doing too much rather than too little; their excesses may aid not at all in the patient's physical recovery but are instead intended solely to forestall his financial recovery in the event of an unsatisfactory result. Although physicians also frequently complain of the hazard of "cookbook" medicine under process-oriented regulatory controls, ${ }^{17}$ the process standards enforced by the fault system are even more pernicious, since they do not make clear where the physician may safely stop and seem to require that everything possible be done. Moreover, because the fault system is administered by lawyers, judges, juries, and partisan experts, all exercising hindsight, physicians have no confidence that realistic standards will in fact be applied. They therefore operate on the worst-case hypothesis and protect themselves as best they can. There is surely a warrant for those reform proposals which would alter administrative arrangements under the present system to improve fault-finding processes, ${ }^{18}$ thereby strengthening doctors' confidence that their conscientious efforts will not be penalized unless demonstrably deficient by reasonable standards.

15. See generally Louisell \& Williams, Res Ipsa Loquitur-Its Future in Medical Malpractice Cases, 48 CALIF. L. Rev. 252 (1960); McCoid, The Care Required of Medical Practitioners, 12 VAND. L. Rev. 549, 605-32 (1959).

16. See 1 D. Louisell \& H. Winliams, Medical Malpractice TTा 8.04.06 (1973); McCoid, supra note 15 , at 558-75, 581-85. The doctrine that adherence to custom in medical practice constitutes due care has long been buttressed by the maxim that a practitioner "experiments at his peril" with unusual methods. Carpenter v. Blake, 60 Barb. 488 (N.Y. Sup. Ct. 1871), rev'd on other grounds, 50 N.Y. 696 (1872); Slater v. Baker, 95 Eng. Rep. 860 (K.B. 1767). Such "experimentation" is of course justified if an innovative treatment offers the patient's best hope and informed consent is obtained. A. Holder, Medical Malpractice LAw 102-03, 249-54 (1975). More broadly, noncustomary practices may be approved if they are the chosen methods of a legitimate "school of practice" or of a "respectable" or "reputable" minority of practitioners. Id. at 44-

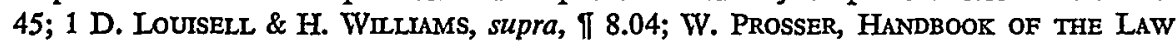
op TORTs 163 (4th ed. 1971); Bovbjerg, The Medical Malpractice Standard of Care: HMOs and Customary Practice, 1975 DUKE L.J. 1375; McCoid, supra note 15, at 565.

17. E.g., Frederick, "Cookbook Medicine": A New Tome Stirs Debate, MED. World News, July 28, 1975, at 61, discussing AMA, Model SCreening CrIteria to Assist Professional Standards Review Organizations (1975); AMA Utges Medical Injury Compensation, AM. MED. NEws, Jan. 13, 1975, at 1.

18. See Comment, State Legislative Responses, supra note 10. 
But, even if the fault system could be substantially improved, perhaps by employing arbitration or screening panels in the assessment of claims, only a few of the foregoing concerns would have been addressed, and none would have been fully resolved. Moreover, there would remain a strong basis for doubt that the legal standard being applied was in fact the socially appropriate one. Although it may seein paradoxical in light of a widely perceived need to improve the quality of inedical care in the United States, the standard of care employed in malpractice suits, based as it is on customary processes and not on outcoines, is probably too high in many respects. ${ }^{19}$ Professional standards, lacking scientific evidence of efficacy and cost-effectiveness, dictate many substantial expenditures which return bittle benefit and may on some occasions increase hazards. ${ }^{20}$ It is a chronic problem in health care that many physicians' decisions taken in the name of the quality of care fail to advance that object either at all or enough to justify the costs entailed, thereby wasting societal resources and perhaps diverting them from more pressing health care needs. ${ }^{21}$

In nonmedical settings, the use of prevailing custom as a guide in assessing negligence is justifed if that standard has been determined by reasonably dependable inarket forces-that is, by buyers and sellers making private decisions with respect to the desirability of added increments of safety. ${ }^{22}$ Where a safety measure thus generally agreed

19. This is not to deny that bad care may sometimes be customary. In some jurisdictions a perception of this state of affairs has led to a narrowing of the customary practice doctrine, based upon Judge Learned Hand's reasoning in The T.J. Hooper, 60 F.2d 737 (2d Cir. 1932). E.g., Darling v. Charleston Community Memorial Hosp., 33 Ill. 2d 326, 211 N.E.2d 253 (1965), cert. denied, 383 U.S. 946 (1966); Favalora v. Aetna Cas. \& Sur. Co., 166 So. 2d 299 (La. App. 1962); Incollingo v. Ewing, 282 A.2d 206 (Pa. 1971); Helling v. Carey, 83 Wash. 2d 514, 519 P.2d 981 (1974). See Note, Comparative Approaches to Liability for Medical Maloccurrences, 84 YALE L.J. 1141, 1146-50 (1975). Although custom-set standards may be either too low or too high by objective measures, this Article stresses mainly the excessive care which doctors may seek to take when their decision-making lacks financial constraints. See Bovbjerg, supra note 16 , at 1396.

20. See, e.g., A. Cochrane, supra note 12; U.S. Public Health Service, Forward Plan For Health FY 1977-81, at 144-61 (DHEW Pub. No. 05-76-50074, 1975); Neuhauser, The Future of Proprietaries in American Health Services, in REgulating Health Facil Ities Construction 233-37 (C. Havighurst ed. 1974).. These sources supply exhaustive further references.

21. See notes 23-24 infra and accompanying text. See generally Havighurst \& Blumstein, supra note 14, at 9-20.

22. See Posner, $A$ Theory of Negligence, 1 J. Legal Studies 29, 32-33 (1972). Although consumer ignorance can frequently be advanced to counter the presumption in favor of market-determined standards, this argument should not be too readily accepted, particularly since markets cater not to the average customer but to the marginal one, who is frequently better informed. Of course, custom would be an inappropriate guide 
upon by buyers and sellers has been omitted by a seller, the buyer's right to sue supphies a useful opportunity to correct, after the fact, a kind of market failure occasioned, it is presumed, by the buyer's ignorance. With respect to medical care, however, custom and practice among practitioners may be a poor guide to appropriate safety-promoting conduct because consumers make few purchasing decisions. Not only are treatment decisions largely delegated to doctors, but, because third parties pay most of the bills, cost is taken into account to only a very himited extent; the physician's fiduciary responsibilities, which at one time included a duty to look out for the patient's pocketbook, are now largely directed to getting the maximum inedical benefit for his patient, regardless of the eost. ${ }^{23}$ Indeed, it is to a large extent the availability of third-party payment which allows the physician to incur the high costs involved in defensive medieine, which, by definition, is undertaken more for the benefit of the provider than for the good of the patient. ${ }^{24}$ In these circumstances, prevailing custom and practice, even if that standard could be perfectly implemented in practice, would be an inappropriate standard. Departure from the fault system and its process-oriented standards would therefore be a positive step froin the standpoint of health policy in general. One of MAI's prime features is its shift of emphasis from process to outcome.

\section{From Fault to No-Fault}

Because the fault systein is dysfunctional in so many respects, alternatives to it must be seriously considered. One alternative is of course siniply to repeal altogether the patient's right to sue a negligent physician, and some substantial limitations on that right have recently been imposed in some states in the form of (1) absolute dollar limits on recoveries permitted ${ }^{25}$ and (2) revised statutes of limitations which arbitrarily cut off claims for undiscovered injuries. ${ }^{26}$ Such piecemeal

for establishing duties toward individuals who were not parties to a contractual relationship with the alleged tort-feasor. See id. at 36-38. On the admissibility of evidence of custom, see generally Darling v. Charleston Community Memorial Hosp., 33 Ill. 2d 326, 211 N.E.2d 253 (1965); McCoid, supra note 15, at 558-75.

23. See Havighurst \& Blumstem, supra note 14, at 13-15, 25-30.

24. See Project, supra note 5, at 942, 946. It is worth observing that the MAI scheme would not limit health care spending except insofar as unproductive defensive medicine was obviated. See note 112 infra. Cost control would have to be achieved by other means, since providers, under MAI or otherwise, have little incentive to seek the optimal level of spending. See notes 48 \& 93 infra.

25. See, e.g., IDAHo CoDE $§ 41-4103$ (Supp. 1975); IND. ANN. STaT. § 16-9.5-2-2 (Burns Supp. 1975). See generally Comment, State Legislative Responses, supra note 10 , at $1418-25$.

26. See, e.g., Fla. Stat. ANN. § 768.28 (Supp. 1975); INd. ANn. Stat. § 16-9.53-1. See generally Comment, State Legislative Responses, supra note 10, at 1429-36. 
repeals are troublesome in much the same sense that wholesale repeal of patients' tort remedies would be, but they have been tolerated primarily out of a desire to maintain the insurability of physicians' liability risks. Aside from measures couched in this expediency, however, repeal of the fault system without introduction of a substitute compensation mechanism has not been seriously proposed. Attention is therefore directed to "no-fault" compensation plans.

\section{The No-Fault Notion as Applied to Medical Care: The FunCtion of DETERRENCE}

\section{A. Compensation or Deterrence as the Goal?}

The medical profession usually responds positively to proposals for a no-fault compensation system for medically caused injuries to patients. This response originates in large part in doctors' anticipation that a nofault scheme would relieve them not only of the psychic and other burdens of malpractice claims and lawsuits but of financial responsibility as well. Thus, in his statement dissenting from the 1973 Report of the Health, Education and Welfare Secretary's Commission on Medical Malpractice, Dr. Charles A. Hoffman, then president of the American Medical Association (AMA), endorsed a compensation plan which would require employers to insure their employees against medical injuries. ${ }^{27}$ Such a plan contrasts sharply, however, with another type of no-fault proposal, which would continue to require providers to bear at least some of the accident costs arising out of the care they render but would dispense with extensive factual inquiries and with fault-finding in individual cases. An essential basis for distinguishing among no-fault plans, therefore, is the extent to which the plan internalizes costs by imposing them in some meaningful way on the providers responsible for the care or externalizes them by passing them on to the public through government or some other third party unrelated to the health care transaction.

How one feels the costs of medical injuries should be borne depends largely on whether one focuses primarily on the need to compensate the mjured patient or also considers it important to motivate providers to avoid compensable outcomes. Dr. Hoffman, stressing only the urgency of compensation for the injured, notes that the "economic need of patients injured in the course of their health care is just as great

27. Medical Malpractice Report $113,127-30$ (C. Hoffman, dissenting statement). See also Editorial, AM. Med. NEws, Jan. 13, 1975, at 4. 
regardless of whether the injury was caused by inalpractice or whether it was an unavoidable risk inherent in the care." 28 But, because the victims of nedical accidents are in no way a needier class than persons who are the victions of disease in general or of other types of accidents, a no-fault medical compensation system cannot be recommended solely on the ground that it would provide compensation for injuries which are now uncompensated.

A better ground for preferring a no-fault scheme is that it is a way of eliminating the problems caused by the existing system while not denying compensation to those who qualify for it now. Indeed, Dr. Hoffman's plan to compensate for medical injuries (including unavoidable events attending recognized risks)-while ignoring for coinpensation purposes other accidental injuries as well as the disease which brought the patient into the health care system in the first place-can best be defended not as a benefit to patients but as a ineans of totally eradicating the inalfunctioning system of inalpractice litigation. Many observers would be reluctant, however, to see problems generated by the law of medical malpractice "solved" by exonerating the negligent physician and eliminating altogether whatever incentives for betterquality care tort law may imtroduce. Attention is thus focused on compensation systems which, while removing inalpractice cases from the courts and avoiding extensive fault-finding, could nevertheless preserve or strengthen the system's quality-enhancing incentives.

The MAI scheine reflects a strong preference for maintaining the tort system's function-however poorly performed it may now be ${ }^{29}$ of deterring medical accidents by inducing close attention to the myriad ways in which they can be prevented or their incidence reduced. It is this rehance on the deterrent effect of financial responsibility for accidents which distinguishes the no-fault approach of MAI from no-fault auto insurance, under which imdividuals must insure themselves and their passengers against mjury but, at least below a certain threshold, have little or no fimancial responsibility for harm done to others. Because the public and their legislatures would probably be more reluctant to absolve physicians from the consequences of their failures than they were to allow unsafe drivers to escape liability to third persons, ${ }^{30}$

28. MediCAL MALPRACTICE REPORT 127-28 (C. Hoffman, dissenting statement).

29. See note 8 supra.

30. For one thing, physicians are readily identified as a special, privileged class seeking exoneration from responsibility for the harms they cause by professional incompetence. E.g., Starr, The Doctor's Discomfort: Malpractice, NEW REPUBLIc, June 28, 1975, at 16. "Unsafe drivers" are not so clearly personified or recognized as special pleaders in the debate over auto no-fault. Moreover, they may seem less blameworthy than the negligent physician and less subject to meaningful sanction under the fault sys- 
legislative action to supersede the fault system for dealing with medical injuries inay be difficult to obtain unless either MAI-type incentives or quality-assurance ineasures of other kinds are introduced.

\section{B. Deterrence Versus Governmental or Professional Quality Controls}

Many observers, but particularly physicians, reject the notion that incentives generated by legal liability for harms can help to improve the quality of medical care. Senator Daniel Inouye, in introducing a no-fault bill which would shift financial responsibility for medical injuries from individual providers to the federal government, ${ }^{31}$ expressed the widely lield behief:

I believe that good doctors practice good medicine in spite of, not because of the threat of malpractice, and that they will continue to do so after the threat is lessened. Conversely, it is questionable whether a deficient or careless doctor can be made to practice good medicine by an external threat. In his case, it is more important that we identify him and take steps to prevent him from endangering the health and lives of his patients. ${ }^{32}$

Senator Inouye's bill, co-sponsored by Senator Edward Kennedy, would impose substantial new regulatory controls on physicians who elected to participate in the projected government-run no-fault imsurance program. ${ }^{33}$ The proposal points up the likelihood that legislative moves to establish a no-fault scheme without a deterrence feature will carry with them stiff substitute controls of the kind which are highly threatening to doctors. ${ }^{34}$

The standard response of the medical profession to the asserted need for increased quality assurance is to look only to professional controls and to resist reliance on either governmental controls or incentives supplied by the fault system or any conceivable substitute for it. Dr. Hoffman's statement referred to above, ${ }^{35}$ while not conceding any significant necessity for strengthened quality assurance, reflected the

tem. Fimally, licensing and policing efforts may seem substantially more effective in curbing ligliway than medical accidents, in part because the enforcement inechanisms are under more effective public control in one case than in the other. Despite these reasons for exonerating negligent drivers, no state has done so completely, suggesting that plyysicians cannot hope to escape continued exposure to liability of some kind.

31. S. 215, 94th Cong., 1st Sess. (1975).

32. 121 CONG. REC. S414 (1975) (remarks of Senator Inouye).

33. S. 215, 94th Cong., 1st Sess. § 1704 (1975).

34. State legislative efforts are revealing a similar expectation of greater submission to public control as a price of malpractice relief. See Brook, Brutoco \& Williams, supra note 6 , at 1223-27.

35. See text accompanying notes 27-28 supra. 
AMA position that peer review is the only appropriate mechanism for achieving whatever quality control is required; his proposal that patients' protection aganist medical injuries be purchased by their employers was obviously designed to place the costs not on government, which would be induced to imterfere further in medical practice, but on parties who were not well situated to introduce or press for quality controls of any kind. Others have suggested that patients insure themselves through a kind of "patient flight insurance," which would be purchased on entry into the hospital or automatically tacked onto every hospital bill. ${ }^{36}$ Such risk-shifting proposals and others seeking to reduce or ehininate the malpractice threat to doctors are nearly always accompanied by an obligatory call for strengthened professional controls over the quality of care..$^{37}$

The view that controls-governmental or professional, as the case may be-are more efficacious than imcentives in maintaining the quality of care is difficult to test empirically, but it is theoretically unsound for at least one reason. Controls necessarily operate by establishing a ininimum level which all providers must meet, and they supply no pressure to exceed that minimum. Incentives, on the other hand, operate on all providers all of the time, encouraging maximum attention to obtaining improved results even on the part of the very best physicians and hospitals. The pressure is thus for performance, not merely for compliance with minimal standards which, whether set by professional groups themselves or by a government bureau imevitably linked by the ties of political influence to organized providers, are unlikely to embody very high aspirations. Controls will inevitably be based primarily on process norms, some of them perhaps validated by outcome studies but all of them hard to change, hard to apply, and hard to reconcile with professional independence. ${ }^{38}$

The preference for controls and against imcentives is traceable in the thinking of both Senator Inouye and Dr. Hoffman to an abiding faith in professionalism and ethics as an adequate guarantor of highquality performance by all but a small minority of physicians, which is presumed to be anienable to governmental or professional policing. Popular as it is aniong physicians, this "bad-apple" theory, in addition

36. See, e.g., Health Policy Analysis Program, The Malpractice Issue in WASHINGTON STATE 87 (Nov. 1975).

37. E.g., Editorial, supra note 27.

38. See Havighurst \& Blumstein, supra note 14, at 25-30; Havighurst \& Bovbjerg, Professional Standards Review Organizations and Health Maintenance Organizations: Are They Compatible?, 1975 Utah L. Rev. 381, 401-04; Note, Comparative Approaches, supra note 19, at 1160-63. 
to attributing all problems to the "other guy," has a slightly elitist ring, suggesting that physicians as a class are worthy of society's trust and that specific guarantees of their good performance can be dispensed with, except around the fringes. ${ }^{39}$ Although Senator Inouye and Dr. Hoffman would obviously lave many differences, the common ground between them is a shared belief that incentives are not a useful mechanism of social control in this important area. ${ }^{40}$

Senator Inouye and Dr. Hoffman to the contrary, however, it is not necessary to cast any aspersion on the average doctor's ethics or notives to suggest that financial incentives may be a useful adjunct to his sense of professional responsibility. One can even concede that a

39. See, e.g., Editorial, supra note 27. Reliance on professionalism and ethics to compensate for consumer ignorance and uncertainty is practically essential in an industry like medical care. Arrow, Government Decision Making and the Preciousness of Life, in Etrics of Health Care 33 (L. Tancredi ed. 1974); Arrow, Uncertainty and the Welfare Economics of Medical Care, 53 AM. EcoN. REv. 941, 949-51, 965-66 (1963). This is not to say, lowever, that opportunities for supplying additional checks on professional performance should be passed by. Cf. Goldfarb v. Virginia State Bar, 421 U.S. 773 (1975) (applying the antitrust laws to the legal profession). For a case adopting the elitist view to limit the force of the antitrust laws in the field of education, see Marjorie Webster Jr. College, Inc. v. Middle States Ass'n of Colleges \& Secondary Schools, Inc., 432 F.2d 650 (D.C. Cir.), cert. denied, 400 U.S. 965 (1970).

40. The common ground between government and the medical profession is apparently large enough to support PSROs, which are extensive peer-review efforts mandated by statute and subjected to extensive federal oversight but controlled and operated by local practitioners. See note 14 supra. See generally Havighurst \& Blumstem, supra note 14. PSROs are being heavily relied upon to control cost and assure the quality of care under federal financing programs, and they provide a base for an effective argument that extension of PSRO review to all care would obviate all other quality controls. See Simmons \& Ball, PSRO and the Dissolution of the Malpractice Suit, 6 U. TOLEDO L. REv. 739 (1975).

It is noteworthy that another view widely shared in both government and the profession is that consumer sovereignty, advertising, private entrepreneurial initiative, and competition have no substantial place in the social control of the health care industry. But cf. Complaint, In re AMA, No. 9064 (F.T.C., Dec. 22, 1975). Just as in the case of quality assurance, the cost controls which must substitute for market imcentives are unlikely to work well and are highly distasteful to physicians. See McClure, The Medical System Under National Health Insurance: Four Models That Might Work and Their Prospects, 1 J. Healtr Pol., PolyCy \& LAW - (1976). Because the medical profession cannot hope to preserve the status quo indefinitely against the demand for stronger government controls, it might be better advised to opt for restoration of a functioning marketplace with limited regulatory oversight as a means of preserving professional independence. Above all, this means accepting health maintenance organizations (HMOs) as active, independent competitors in a inarket conducive to their operation. See id.; Havighurst \& Blumstein, supra note 14; Havighurst \& Bovbjerg, supra note 38 . On the subversion of HMOs by a combination of Congressional liberals and the AMA, revealing the confluence of views on the undesirability of allowing markets to function, see Starr, The New Medicine: An Experiment Designed to Fail, New REPUBLIC, Apr. 19, 1975, at 15; Starr, The Undelivered Health System, 42 PUB. INTEREST 66 (1976). 
highly developed sense of ethics is a hallmark of the profession-I personally believe that it is-, yet recognize that this ethical sense is not distributed in precisely equal proportions. For the physician who feels no overwhelming ethical responsibility to maintain his competence or to limit his practice so as to honor the principle that he should "first, do no harm,"41 it is highly likely, contrary to Senator Inouye's suggestion, that financial incentives will be quite meaningful.

As to even the above-average doctor, his no doubt strongly felt ethical obligation is to do what he was taught in inedical school and what lie sees other doctors doing for their patients; he is probably largely content to know that he is doing the best lie knows how under frequently difficult circumstances. Yet there is lacking in his consciousness an awareness of how his results compare with the results achieved by other doctors. He lias hittle feedback of information which might put him on notice that his efforts are misdirected, that improvements are possible, and that his best is not quite good enough. But with financial incentives based on the quality of outcomes and with claims experience supplying a convenient basis for comparing his performance with that of other physicians, such a physician would be induced to re-examine his methods, to seek advice and continuing education, to follow up with patients to check compliance with regimens and to discover new probleins, and, finally, to hinit his practice to those problems which he is most capable of handling successfully.

The recent Study on Surgical Services for the United States (SOSSUS) illustrates the medical profession's approach to solving quality-of-care problems. A plea is made for developing a "rehable data base for quantifying surgical excellence," a step said to be necessary "[i]f good surgeons are to be encouraged to operate inore and poor ones less or not at all; if good hospitals are to be expanded, mediocre ones improved, and poor ones closed." ${ }^{2}$ It is reasonable to expect, however, that a system of outcome-oriented incentives would achieve these goals far sooner than inethods such as those contemplated in the SOSSUS report. ${ }^{43}$ Not only is it umecessary to wait for a definitive

41. Physicians are familiar with the principle primum non nocere: "First, do no harm." This appears to trace back to Hippocrates. See 1 HIPPocrates 165 (Loeb Library ed. 1923).

42. American College of Surgeons \& American Surgical Ass's, Surgery in THE UNITED STATES 192 (1975) (SOSSUS Report).

43. For an expression of government's concurrence on the means to be adopted, see ForWARd PLAN For HeALTH, supra note 20, at 23:

[M] $t$ is the shared responsibility of health professionals and government to provide a reasonable basis for confidence that action will be taken both to assess 
"data base," 44 but it is also unnecessary to implement inevitably debatable quality standards by applying specific sanctions against powerful professionals whose resistance to outside interference is legendary. Perhaps the profession can proceed against a tiny minority of incompetents who allegedly give the profession a bad name, but there is no way that across-the-board direct controls over surgeons and hospitals can ever be finely tuned to achieve overall effectiveness. ${ }^{45}$ Only an unobtrusive, nonpolitical system of rewards and penalties can hope to achieve the worthy objectives specified in the SOSSUS report. Unfortunately, the gap between stating these objectives and realizing them by the means specified is so great that one may be forgiven for suspecting that the surgeons are more interested in demonstrating their good intentions than in measurably improving the fraternity's performance.

whether services meet professionally recognized standards and to correct any deficiencies that may be found. Quality assurance is thus not a guarantee of performance, much less of satisfactory results, but an iterative process that leads to improved health care quality. The quality assurance process consists of the following steps:

i. Developing and disseminating knowledge regarding the efficacy, safety, and cost of medical procedures;

ii. Developing and disseminating knowledge regarding methods of assessing and improving the quality of health care interventions, and

iii. Establishing organizational and administrative entities that can use the information from steps 1 and 2 to assess and, through a variety of mechanisms, improve the quality of performance, and which can contribute to the development of new information.

44. See also id. (noting major deficiencies in the "knowledge" required for quality assurance). It is reasonable to expect that the research studies needed to enlighten the profession on quality-related matters would be more aggressively pursued by professional groups such as PSROs and the SOSSUS sponsors if providers had a direct financial stake in improving outcomes. The MAI system itself would supply valuable data on outcomes and, even more important, would feed it back, in the form of higher or lower costs, to individual providers for immediate action.

45. Most observers maintain faith that the obstacles to effective managenent of the systein's quality can somehow be overcome, but there is recognition that much remains to be done:

Methodologies for assessing health care quality and methods for influencing provider performance are still primitive and need further development and critical examination. Without a sound methodological underpinning, quality assurance activities cannot ensure accountability for provider performance, nor can the relationship between medical practice (process) and patient benefit (outcome) be adequately documented.

... [I]t will not be possible to assure quality without an administrative structure to see to it that the practice is aligned with theory. Id. at 23-24.

It is fair to say that hardly any responsible person in the health care system recognizes any alternative to the peer-review method of quality assurance. It is far from clear, however, that thc entire $\$ 110$ billion health care enterprise can be centrally managed by expanding a mechanism which has so far had its only pronounced success at the institutional level and whicl is heavily dependent on providers' commitment and acceptance to make it function well. 


\section{What Providers Stand to Gain From an Outcome-Oriented Incentive System}

Although providers will probably resist adoption of MAI or any other incentive-oriented quality-assurance mechanism, they may in fact have something to gain froin it. As previously noted, it seems unlikely that substantial rehef from malpractice suits will be granted without adoption of new quahty-assurance measures to compensate for the loss of the perceived quality-enhancing benefits of the fault system. Physician accountability lias become a watchword among reformers, and most mechamisms for increasing it should seem substantially more threatening to physicians than MAI. Even if extensive legislative rehef from the inalpractice burden is obtained, the special treatment thus accorded to doctors-"class legislation" it is being called in some places - will be charged up against them in the political ledger, to be balanced later on. On the other hand, if providers were willing to stand behind their work to the limited extent contemplated by MAI, the seemingly mexorable pressure for imcreased intervention in their decision-making miglit be reduced. The profession's political image would be inproved, and, if MAI worked well, a persuasive case could even be made for rolling back some existing regulation. ${ }^{46}$

The outcome-oriented character of the MAI approach should also have particular appeal to providers. Concerned about "cookbook" medicine and defensive practice, they should respond positively to a quahity-assurance mechanism which addresses results alone and pays little or no attention to how they were achieved. Although no imputation of fault should arise from payment of an MAI claim, the provider may well be induced to examine both his conscience and his methods by the reminder that reasonable expectations of a good outcome have been disappointed. But professional independence would remain inviolate, and providers could adopt whatever methods seemed to them, in the exercise of their scientific learning and professional judgment, most likely to be beneficial. All visible indications are that physicians value their independence highly. MAI, by offering physicians the only responsible basis on which their right to exercise independent professional judgment can be preserved, challenges them to reveal whether they in fact value smiply their present nonaccountability for most bad outcomes. ${ }^{47}$

The incentives needed to make MAI work could probably be established without imposing on providers financial costs which seemed

46. See note 133 infra.

47. See notes 6-8 supra and accompanying text. 
punitive. Indeed, a provider's cost flowing from the occurrence of a compensable outcome should probably be viewed more as a firm reminder than as a punishment, and certainly no provider should face the possibility of being wiped out by a run of bad luck. Although arriving at the appropriate level of direct provider responsibility would be difficult, ${ }^{48}$ the program must appear to achieve substantially increased accountability if it is to inhibit the trend to ever-stricter controls. It does not seem necessary, however, that it be even as threatening to the average physician as the malpractice systein seems to be. It should, of course, seem substantially fairer to physicians than the prevailing system and reasonably consistent with recognized professional obligations. Fortunately, it seems probable that these conditions can be inet in a plan which, by reducing administrative costs, increases the nuniber of dollars available for compensating patients and allows expanding the number of injuries for which compensation will be paid.

\section{Supplying Incentives Under MAI}

The central tenet of the MAI scheme is that financial incentives supplied by liability rules can be a major guarantor of good-quality medical care. Because of liability imsurance and insurer rating practices, such financial incentives are an insignificant factor under the fault system, which appears to rely primarily on stigmatization and the unpleasantness of the litigation process to frighten providers into avoiding claims. Because MAI dispenses with most of the in terrorem effect of the fault system, it must deter accidents by introducing more effective financial incentives. ${ }^{49}$ The mechanics of supplying effective in-

48. Incentives for good care would not necessarily be too weak under MAI even if substantially less than the full cost of accidents were borne by the responsible providers, since providers are not usually in a position of balancing the saving froin preventive measures against the cost of taking them. See note 93 infra. The argument for deterrence under MAI is therefore not the saine as that offered for strict liability in other areas-namely that optimizing behavior will be induced. See generally G. CALABREsI, The Costs of Accidents 135 et seq. (1970); Calabresi \& Hirsclioff, Toward a Test for Strict Liability in Torts, 81 YALE L.J. 1055 (1972); Note, Comparative Approaches, supra note 19, at 1150-57 (discussing the applicability of tort theory to the malpractice problem without clear recognition of the impossibility of achieving optimal deterrence with present financing mechanisms). For a fuller discussion of this aspect of MAI and particularly its potential impact on inducing optimal performance by HMOs, see Havigliurst \& Tancredi 159-63, 94-96.

49. One possible qualitative loss from reducing physicians' malpractice fears could not be made up under MAI. Although MAI makes providers accountable for technical results, the narrowing of the patient's discretion about whether to initiate a malpractice lawsuit might reduce providers' incentives to cultivate good relationslips with patients. See note 8 supra. Nevertheless, malpractice law is alleged to affect doctor-patient relations adversely in other respects, and the expanding physician supply, new grievance pro- 
centives are potentially complex..$^{50}$

The original MAI proposal contemplated that highly individualized experience rating in setting MAI premiums would serve to provide the desired incentives for quality assurance. The assumption was that some of the cost of each compensable outcome could be charged in some relatively direct way to the insured provider and to those other participants in the health care system who might be able to influence the frequency of such events, perhaps through strengthened peer-review efforts. ${ }^{51}$ This approach, while rational as an incentive-preserving mechanism, involves some departure from established insurance principles, which are primarily concerned with the likelihood of future occurrences and not with distributing the costs of past events. Indeed, the primary purpose of liability insurance im general las been to relieve responsible parties of the costs associated with imsured events, thus weakening incentives to avoid them. Although insurers in other areas have revealed some concern with accident avoidance, malpractice insurers have shown little interest in using rates either for deterrent purposes or as a recoupınent measure even if desirable incentives for claims reduction would result..$^{52}$ One hopes that the actuaries called upon to implement MAI could be induced to take an active interest in doing more than passively assembling the funds to pay future claims.

cedures, and greater emphasis on consumer choice and advertising could also offset any loss which might be feared. The law of informed consent, which would not be affected by MAI, might also play an important continuing role. See, e.g., Canterbury v. Spence, 464 F.2d 772 (D.C. Cir.), cert. denied, 409 U.S. 1064 (1972); Cobbs v. Grant, 8 Cal. 3d 229, 502 P.2d 1, 104 Cal. Rptr. 505 (1972); Note, Restructuring Informed Consent: Legal Therapy for the Doctor-Patient Relationship, 79 YALE L.J. 1533 (1970).

50. The costs borne by providers must have a direct impact and not be passed through to some third party. Although doctors are thought by some to be free to pass costs on to their patients, there are substantial limits to their ability to recoup in this fasbion, and no physician would be wholly indifferent to his costs. It is clear that providers should not be able automatically to treat their actual premiun costs or cost-sharing outlays as expenses for purposes of determining fees under fee schedules or costrelated reimbursement; rather, the average outlay for providers similarly situated should be so treated, leaving the provider free to profit from any lower premiun resulting from good past experience and exposed to a loss from higher premiums. If the tax laws should continue to permit a business deduction for actual imsurance premiums and payments under cost-sharing provisions, INT. REv. CODE OF $1954 \$ 162$, the government would, in effect, share the cost of a provider's poor performance. Under these circumstances, a substantially larger premium or cost-sharing obligation would be required to make incentives meaningful.

51. See Havighurst \& Tancredi 129-30, 140, 162-63; 72-73, 80, 96.

52. The random incidence of claims, see notes 6-7 supra, under the present system suggests that past claims inay be poor indicators of future ones and that it would not be rational to set premiums in relation to experience. Practice appears to be that premiums are raised only after several claims. See Steves, supra note 4 at 1322; Roddis \& Stewart, The Insurance of Medical Losses, 1975 Duke L.J. 1281. 
The mandatory and highly detailed experience rating contemplated in the original MAI proposal would require legislation and administrative oversight to achieve the fine-tuning visualized. ${ }^{53}$ While an alternative possibility would be simply to define the events which must be covered and allow insurers to develop their own rating categories, this approach might fail to yield meaningful imcentives. Not only have malpractice insurers not been accustomed to much imdividualizing of premiums, but actuarial considerations, dictating that rates be set only for large, non-self-selected groups, give the market some natural monopoly characteristics. Moreover, insurance regulation reinforces the inonopohstic pattern and further retards the kind of competitive pricing innovation required to make MAI effective. Despite these reasons for fearing that insurers acting alone im implementing the no-fault model might not greatly strengthen provider imcentive, one characteristic of MAI offers hope: the larger number and increased predictability of insured events under MAI would facilitate experience rating, ${ }^{54}$ thus perhaps allowing meaningful imcentives to be achieved without regulation which was unduly disruptive of existing insurance practices.

If experience rating could not be expected as a spontaneous development, a possible means of creating quality-assurance incentives in an MAI program without extensive interference with the imsurance imdustry would be simply to impose a share of the cost of each claim directly on the responsible providers through some kind of deductible or coimsurance requirement. The possibilities are limitless, but appropriate incentives could probably be achieved without imposing large costs on individual providers. For example, the insured provider might be inade responsible for, say, ten percent of each claim up to $\$ 50,000$, with such amounts to be reimbursed to the insurer as part of future premiums over a five-year period. An alternative, or additional, mechanism would be a deductible under which an insured physician would pay the first, say, $\$ 10,000$ of claims in any year and would profit by that aniount if he avoided all compensable events. Cost-sharing arrangennents might differ for different events, perhaps taking effect only after a certain number of claims had been paid and thus reflecting the degree to which a certain number of such events were thought to be unavoidable.

53. Different experience-rating formulae were contemplated for different events, so that incentives could be tailored to the needs of the particular case. See Havighurst \& Tancredi 140, 80 .

54. See notes 6-7 supra and accompanying text. Experience rating is deemed feasible in.workmen's compensation when premiums exceed $\$ 500$ per year. NAT'L CoMM'N ON STATE WORKMEN's COMPENSATION LAWS, REPORT 98 (1972). 
It is possible that insurers providing no-fault coverage would voluntarily offer policies with coinsurance or deductible features. ${ }^{55}$ These features would reduce premiums and would be attractive to those providers who anticipated few claims and therefore saw an advantage in limited self-insurance. If the insurance industry appeared insufficiently competitive to produce this self-insurance option spontaneously, it might be inade mandatory by legislation or by state insurance regulation.

The ineclianism for establishing a reasonable set of incentives for accident deterrence carmot be specified without furtlier study of the insurance industry, the available techinques for distributing costs, and the advantages and difficulties of tailoring the impact to fit particular cases. As to some situations at least, it seems likely that regulatory attention would be desirable to fime-tune incentives and to assure that insurance rating practices did not neglect deterrence. Legislation to establish MAI should charge the administrators with responsibility for developing a reasonable deterrence feature through the use of sucli regulatory powers as were necessary to inake it work both fairly and effectively.

\section{The No-Fault Notion as Applied to Medical Care: COMPENSABLE EVENTS}

\section{A. The Complexities of Identifying Compensable Events}

Several examinations of the prospects for employing no-fault concepts to relieve the medical inalpractice crisis liave concluded that the problems confronted in identifying conipensable events are extremely great, perhaps insuperable. ${ }^{56}$ The chief problein is that inany variables, including patient idiosyncrasies, may determine the effects of a given medical treatinent and the extent of any injury, so that inany bad results can be as easily regarded as incidents of the patient's presenting condition as attributed to a "inedical injury." Unless the no-fault scheme is to be simply a social insurance plan indemnifying as many losses as possible, some notion of preventable liarm seeins needed to identify compensable events. ${ }^{57}$ Unfortunately, attention to prevent-

55. However, such spontaneous cost-sharing provisions would probably not produce the same incentives for peer review contemplated in the MAI proposal. Havighurst \& Tancredi 139-40, 162; 80,96.

56. Medical Malpractice Report 101; Roth \& Rosenthal, Non Fault Based Medical Injury Compensation Systems, in MediCAL MALPRACTICE REPORT Appendix 450; Note, Comparative Approaches, supra note 19; Keetou, Compensation for Medical Accidents, 121 U. PA. L. Rev. 590, 615 (1973). Carlson, Conceptualization of a No-Fault Compensation System for Medical Injuries, 7 LAw \& Soc'y Rev. 329 (1973).

57. The cost of a program to compensate all "medical injuries" or all iatrogenic injuries would be considerable. Two studies conducted for the HEW Secretary's Commis- 
ability would open up questions very similar to those involved in applying the fault system (suggesting that "no-fault" would be a misnomer) and would invite second-guessimg of almost any outcome less than full recovery. To avoid such inquiries, proposals for comprehensive no-fault coverage have drawn the line defining compensability on the basis of whether the cause of any bad result is to be found in the patient's disease or in the medical care system itself. Iatrogenicity is thus the key to such comprehensive no-fault plans. ${ }^{58}$

The apparent necessity under a comprehensive no-fault system for determining the cause of every resulting condition has led Professor Robert Keeton to question the advantage of such a system over the present one. ${ }^{59} \mathrm{He}$ suggests that the administrative cost in time and money of determining causation, when added to over-all cost increases due to an increase in the number of claims, may not be worth the gains in the form of a diminished threat to the reputations of physicians and standardization of compensation payments. The vast amount of hitigation spawned by the "work-relatedness" of injuries under workmen's compensation serves as a warning against leaving too many factual issues open to dispute. ${ }^{60}$

Despite the foregoing reasons for despair over the prospects for a no-fault system, the MAI proposal offered a tentatively hopeful view.

sion on Medical Malpractice revealed that substantial percentages (8.5 percent and 7.6 percent, respectively) of hospitalized patients suffer some medical imjury. See Boyden, Medical Injuries Described in Hospital Patient Records, in Medical Malpractice RePORT Appendix 41 (declining to state the 8.5 percent figure in part because the sample was not necessarily unbiased); Pocmcki, Dogger \& Schwartz, The Incidence of Iatrogenic Injuries, in MEDICAL MALPRACTICE REPORT Appendix 50, 55.

58. The studies by Boyden, supra note 57, and Pocincki, Dogger \& Schwartz, supra note 57, both applied a causation test, as would the compensation schemes proposed by S. 215, 94th Cong., 1st Sess. (1975). See note 60 infra. See generally Medical MaLPRACTICE REPORT 113 (C. Hoffman, dissenting statement); and Roth \& Rosenthal, supra note 56 .

59. Keeton, supra note 56. Professor Keeton is not unfriendly to the no-fault idea, only unconvinced of its utility in this particular setting. Moreover, he was writing before the MAI proposal was published.

60. See generally 1 A. LARSON, The LaW of Workmen's Compensation ch. III (1972). Some inkling of the administrative fact-finding burden which would be entailed by an open-ended no-fault scheme can be gained from the language of the KennedyInouye no-fault bill, S. 215, 94th Cong., 1st Sess. (1975). This bill would provide "compensation for loss from any injury suffered as a result of health care services provided by an insured . ..." Id. $\$ 1711$ (a). The bill further specifies that "an injury 'results' from the provision of health care services when it is more probably associated in whole or in part with the provision of such services than with the condition for which such services were provided." $I d . \$ 1721(8)$. If the draftsmen did not really intend to nake all evidence of possible intervening causes inadmissible, see, e.g., Havighurst \& Tancredi 147-49, 85-87, the final phrase should read "than with some other cause." In either event, it is not clear how patients' idiosyncracies would affect compensability. 
It suggested that case-by-case adjudication of medical injuries and exposure to unmanageable costs could be avoided if a highly specified list of coinpensable injuries were developed in advance and incorporated in an insurance policy covering only those injuries, leaving other adverse outcomes to be liandled under traditional doctrines and procedures, lrowever they might be modified. Ideally, the list of events compensable under the MAI policy would be developed in sucli a way that each event would be readily recognizable wlien it occurred, with no occasion for further inquiry as to its etiology. ${ }^{61}$ An event would be added to the list if medical opinion indicated that the event was usually or frequently-though by no means invariably-avoidable under good-quality medical care and that the frequency of the event could be expected to diminislr if providers' attention were directed more strongly to the quality of the outcomes being achieved. Not all malpractice cases would be removed from the courts under this plan, but many would be. ${ }^{62}$ Moreover, the list would be lengthened over time, beginning with the most obvious occurrences and later expanding to cover outcomes which, though seldoin the subject of a lawsuit, were deemed avoidable in inany instances.

Although the original MAI plan tentatively suggested some injuries for inclusion on the list of compensable events, its primary emphasis was on the analytics of list compilation. It stressed the necessity for fairness in not including events which in the contemplation of providers are very often unavoidable, althougln it argued the legitimacy of including some unavoidable events wherever necessary to eliminate a causation issue or to achieve another practical objective. Providers were urged to recognize that, while avoidability of an event is a factor in its inclusion on the list and the major goal of the system is to prevent avoidable events, the system nevertheless remains a "no-fault" sclieme since blame is not in fact assessed in specific cases. Although pliysicians may resist the strict liability notion of automatic payment for outcomes which are sometimes unavoidable, it is in fact the inclusion of some unavoidable events in the listed outcomes which would shelter the provider from any imputation of fault whenever a patient suffers a compensable harm. There are thus positive advantages to providers, as well as to patients, from including some unavoidable events within the coverage of the compensation scheme. Even so, plysicians (and others) contemplating MAI continually slip back into equating liability

61. See Havighurst \& Tancredi 143-50, 83-88 (detailed illustration of the process of listing an event-liepatitis contracled within six months following a blood transfusionin such a way as to exclude debate over causation).

62. See note 107 infra. 
with blame, revealing that getting people to accept fully the notion of liability without fault requires considerable re-education. ${ }^{63}$

The criteria for listing an event as compensable would mclude several other factors in addition to the event's relative avoidability and the ease with which its occurrence or nonoccurrence could be established in specific instances. One complex issue is presented by the need to guard against the danger that making an adverse outcome of one course of treatinent compensable would distort rather than improve treatınent decisions, perhaps by causing providers to select a less appropriate treatinent inode because of a reduced likelihood of a compensable outcome. ${ }^{64}$ The ability of various providers engaged in the treatment process to take direct or indirect action to prevent or minimize harm would also have to be considered in deciding whose MAI policy should cover a particular event. ${ }^{65}$

Another factor which would undoubtedly enter into the specification of compensable events is the need of patients for compensation, which would be sinall wherever the inam expense was inedical costs largely covered under other prograins. ${ }^{b 8}$ However, adherence to the principles of MAI would caution against excluding at least highly avoidable events from compensation on this ground, since it would mean losing an opportunity for injury deterrence. The saving to the MAI prograin froin excluding such events might be inuch less than the contimued cost of avoidable injuries to other public and private financing programs.

63. Perhaps the best way to conceptualize liability without fault is to recognize that a loss has already occurred and that it is a legitimate social issue whether the loss should be left where it falls, subject to any insurance which the victim may have obtained, or should be shifted by legal means to someone else. The social cost of shifting the loss can ouly be justified if some offsetting benefit appears, but such a benefit may be found in improved incentives. Thus, it may not be at all difficult to justify placing the risk on a hospital or physician, either of which is almost always in a better position than the patient to minimize the risk by direct action or by inducing different behavior by the patient or by other participants in the treatment. See CALABRESI, supra note 48; Calabresi \& Hirschoff, supra note 48. Pliysicians are already exposed to various kinds of vicarious liability-under the doctrines of respondeat superior, "borrowed servant," and the "captain of the ship"-based on similar principles. See note 89 infra. Despite the clear legitimacy of the no-fault liability principle, the MAI proposal nevertheless expresses a concern for physicians' perception of fairness and would push the bounds of liability only as far as quality gains were reasonably in prospect. See Havighurst \& Tancredi 135-39, 77-79.

64. See text accompanying notes 99-106 infra.

65. See text accoinpanying notes 97-99 infra.

66. See text accompanying notes 110-15 infra. Malpractice claims are probably less likely to occur where the patient bears no out-of-pocket financial loss. Viewing MAI primarily as an answer to the problem of malpractice claims would therefore dictate its coverage of other areas first. 
Expected dollar cost is probably an inevitable additional factor in listing compensable events, since introducing compensation where it is not now paid would be expensive. Although the theory of MAI would not admit cost as a legitimate consideration, ${ }^{67}$ it probably could not be ruled out as a practical matter in a functioning program.

\section{B. Progress in Developing a List of Compensable Events}

The suggested compensable events in the original MAI proposal were merely illustrative of possibilities. ${ }^{68}$ The only set of events carefully considered at that time was blood transfusion reactions. ${ }^{69} \mathrm{Al}-$ though the MAI proposal contemplated extensive professional investigation of numerous events which were candidates for the list, no professional groups liave taken up the project, and it has not been possible to involve physicians extensively in subsequent investigations. The results of further specification efforts are therefore still highly tentative.

Our reccnt efforts toward compiling a defimitive hist of compensable events have concentrated on anesthesiology and general surgery. ${ }^{70}$ The approaches taken in these two areas liave differed substantially, and the differences are useful in illustrating the possibilities and flexibility of MAI.

\section{General Surgery}

Compensable outcomes for general surgery have been tentatively specified both with respect to surgery of all kinds and with respect to specific procedures. ${ }^{71}$ The proposed list of compensable events in this area is as follows:

67. See text accompanying notes 109-12 infra.

68. Havighurst \& Tancredi 134, 76.

69. These were deemed appropriate for compensation under a hospital-purchased MAI policy even in the case of certain hepatitis reactions which were neither clearly avoidable nor clearly caused by the transfusion. Id. at 143-50, 83-88.

70. The original proposal addressed orthopedics imjuries. Id. at 133-35, 75-76. See also Tancredi, Identifying Avoidable Adverse Events in Medicine, 12 MED. CARE 935 (1974).

71. The list was compiled by reviewing the most common surgical complications and considering thein in light of the following questions:

1. To what extent is the incidence of this complication related to the technical skill, judgment, or attentiveness of the surgeon?

2. Is this complication a clinically distinct entity? Can its existence be readily substantiated?

3. How early in the postoperative period is this complication detectable?

4. How costly are the sequelae of this complication?

5. Would an incentive to minimize the occurrence of this complication bias the choice of treatment in unfortunate ways?

The primary source consulted was Management of Surgical Complications (3d ed. C. Artz \& J. Hardy 1975).

The most obvious candidates for a list of compensable events are those which courts 


\section{General}

1. Foreign bodies acquired intraoperatively

2. Burns acquired intraoperatively

3. Injury resulting from severance of an indwelling plastic catheter $^{72}$

4. Neurological deficit resulting from intramuscular injection

5. Injury resulting from mistaken identity

6. Injury resulting from inadvertent intravascular mjection of local anesthetic

7. Postoperative wound dehiscence in noncarcinomatous patient under age forty-five ${ }^{73}$

8. Tetanus infection subsequent to treatment of wound

9. Severe reaction to administration of tetanus antitoxin [on irreversible neurological damage or death following intraoperative cardiac arrest or spiral anesthesia, see Anesthesiology below].

\section{Procedure-specific}

\section{Parathyroid surgery or thyroidectomy}

10. Permanent recurrent laryngeal nerve damage ${ }^{74}$

would treat under the doctrine of res ipsa loquitur; there seems little to be said for caseby-case litigation of claims based upon foreign bodies acquired intraoperatively (\#1), burns acquired intraoperatively (\#2), surgical procedures erroneously performed on the wrong patient (\#5), and a hemolytic reaction to a blood transfusion (\#25, see also Havighurst \& Tancredi 144,83 ).

72. The relative avoidability of this complication is illustrated by the striking diminution of its incidence as practitioners lave becolne more aware of the technical mistake whiclı creates the difficulty. "Sucli occurrences can be minimized by careful attention to the mauageinent of the catheter and the catheter site as well as the utilization of radiopaque catheters and the careful measurement of the length of the catheter before insertion and after removal." Moncrief, Complications of Parenteral Fluid Therapy, in MANAGEMENT OF SURgiCAL Complications, supra note 71, at 68, 75.

73. "Studies have shown that a few surgeons will have many wouuds with dehiscence and others will have extremely few. Surgical technique is important." Hunt, Wound Complication, in Management of SuRgical Complications, supra note 71 , at 21, 25. A number of technical errors are known to increase the likelihood of dehiscence. Other variables, such as age and condition of the patient and the type of operation performed, also affect the mcidence of this coinplication. Restricting compensability to patients under forty-five would lielp to screen out the effects of the principal variables that he beyond the surgeon's control.

74. "In the hands of competent surgeons experienced in exposing the recurrent laryngeal nerves, permanent nerve injury occurs in less than 1 per cent of cases." Hardy, Complications of Thyroid and Parathyroid Surgery, in MANAGEMENT OF Surgical COMPLICATIONs, supra note 71 , at 291,300 . Technical skill and attentiveness are probably 

11. Postoperative hypoparathyroidism exceeding two weeks' dura- tion $^{75}$

Thyroidectomy or tonsillectomy

12. Death in the immediate postoperative period ${ }^{76}$

\section{Cholecystectomy}

13. Injury to common bile duct ${ }^{77}$

\section{Venous stripping}

14. Injury from imadvertent stripping of femoral artery

\section{Gastrointestinal procedures}

15. Inadvertent gastroileostomy ${ }^{78}$

16. Duodenal stump leakage following gastric resection ${ }^{79}$

17. Instrumental perforation of esophagus ${ }^{80}$

the key variables determining the incidence of the complication. Permanent abnormal phonation and serious respiratory obstruction are the sequelae involved.

75. If all four parathyroid glands are inadvertently removed during surgery, hypocalcemic tetany will result, and lifelong drug therapy will be necessary to compensate for the activity of the removed glands. "In a review of 600 cases of thyroid surgery . . 17 (2.8 per cent) cases of transient postoperative hypocalcemic tetany and nine (1.5 per cent) cases of permanent hypoparathyroidism [were found]." Id. Preserving the parathyroids during total thyroidectomies for thyroid malignancy is a difficult technical feat; for this reason some may suggest that compensability be restricted to patients without thyroid malignancy. Others may argue that precisely because of the difficulty of the procedure, the adverse outcome should be made compensable to deter less technically competent surgeons from attempting the operation.

76. Careful observations in the postoperative period will prevent the fatal consequence of uncontrolled hemorrhage. "The most distressing fact is that, though this hazard and possible sequelae are well known on all active surgical services, every 3 or 4 years in most general hospitals some patient loses his life from this cause." Id. at 296. Designating "death" as the compensable event rather than "postoperative hemorrhage" serves three goals: (1) Death is obviously not subject to the definitional problems inherent in a term like "hemorrhage." (2) Hemorrhage promptly noticed and controlled will not result in mjury significant enough to compensate. (3) While the hemorrhage itself is of questionable avoidability, the surgeon can affect the consequeuces of hemorrhage by careful postoperative monitoring.

77. Careless dissection and blind clamping of bleeding vessels can produce an imjury to the cominon bile duct. "Perhaps less thau half of those who sustain a stricture due to operative injury survive for 10 years." Glenn, Complications Following Operations Upon the Biliary Tract, in Management of Surgical Complications, supra note 71, at 501,521 .

78. This technical error can be avoided by careful identification of anatomical structures. Its occurrence necessitates reoperation.

79. Duodenal stump leakage is the niost serious common complication and the main source of mortality in gastric resections. Surgical judgment, technical skill, and postoperative management are among the variables affecting its imcidence.

80. As the use of instrumentation in the treatment of GI conditions has increased, instrumental perforation of the esophagus has ennerged as a serious complication. This outcome is relatively avoidable. 


\section{Gynecology 81}

18. Perforation of uterus during dilatation and curettage

19. Vesicovaginal, ureterovaginal, rectovaginal, or enterovaginal fistula following gynecological procedure on noncarcinomatous patient

20. Permanent damage to ureter

\section{Prostatectomy}

21. Rectal injury

22. Permanent urinary incontinence

\section{Treatment of fracture}

23. Nerve paralysis following treatment with straps, splits, or casts ${ }^{82}$

24. Function-impairing deformity from inalunion of fracture ${ }^{83}$

\section{Blood transfusion}

25. Heinolytic reaction ${ }^{84}$

26. Bacterial sepsis

27. Serum lepatitis ${ }^{85}$

\section{Nephrectomy}

28. Nephrectomy in the absence of a normally functioning contralateral kidney

It is stressed that the various items on the foregoing list are subject to further specification, which might rule out compensation for patients with a special predisposition toward the result if that predisposition could be clearly identified in practice. Clinicians' assistance is clearly necessary in refining the list in this and other ways. ${ }^{86}$ It should be noted that postoperative wound infections are omitted from the list, although they were nominated for inclusion in the original proposal. ${ }^{87}$

81. These complications are highly avoidable.

82. "Delayed nerve paralysis is practically always secondary to faulty treatment." Hampton, Complications of Common Fractures, in MaNagement of SURGICAL Complcatrons, supra note 71 , at $699,708$.

83. "The term 'malunion' really implies union of a fracture in a function-impairing deformity which could have been prevented by more skillful management of the fracture." Id. at 709-10.

84. Havighurst \& Tancredi $144,83$.

85. Id. at 144-50, 83-88.

86. See note 104 infra and accompanying text.

87. Id. at 134, 76. An explanation of the reasoning behind the decision not to in- 


\section{Anesthesiology}

In anesthesiology, highly detailed specification of events compensable under MAI, such as has been attempted for general surgery, is appropriate for dental and peripheral nerve imjuries occurring under anesthesia, and such mjuries should be included on the hist covered by the anesthesiologist's MAI policy. This piecenneal approach seems inadequate, however, to manage the nnost serious adverse consequences of anesthesia, namely death or irreversible central nervous systein damage occurring in a wide variety of surgical circumstances. Although a more sweeping approach is indicated to cover such outcomes, undertaking to compensate all such injuries and deaths occurring during or shortly after the operation seems likely to encompass many occurrences which are essentially unavoidable, being attributable to the patient's deteriorated condition and the inherent risks of surgery. For example, the operative death of an elderly patient with numerous physiological disturbances or of a victim of a gunshot wound to the chest does not raise the same presumption of avoidability which attends the death of a young adult undergoing a gall bladder operation.

Because establishing "operative death" as a compensable event is too nonspecific to assure that the goal of fairness is being realized, it is desirable to separate, in at least a rudimentary way, those fatal cardiac arrests and central nervous systein injuries under anesthesia which are likely to be avoidable from those whicli are not. One possible approacl is to inquire deeply into the patient's condition and the particular practices (dosage, type of ventilation, and so forth) employed, but this approach would necessitate costly case-by-case inquiries. A simpler and more outcome-oriented approach is to adopt a broad classification which excludes some patients on the basis of age and the urgency

clude this particular adverse outcome as a compensable event may help illustrate the application of the relevant criteria for selection. Postoperative wound infection is unquestionably an adverse outcome of sizable significance; some studies have indicated that a serious postoperative infection results in an average cost of approximately $\$ 7,000$ per patient to the natioual economy. Hardy, Surgical Complications, in Texrвook of Surgery 398, 404 (10th ed. D. Sabiston 1972). Nevertheless, reluctance to designate "postoperative wound infection" as a compensable event is justified for the following reasons: (1) It is not a clinically distinct entity. Some infections are trivial; others are life-threatening. Serious definitional difficulties could be anticipated. (2) Variables other than those within the surgeon's control are primarily determimative of its incidence. "The incidence of wound infection varies from less than 1 per cent in clean primarily closed wounds to 25 per cent or more in wounds created by emergency operations on the injured colon or perforated appendix." Hunt, supra note 73, at 28 . The type and location of the wound, the type of micro-organisms imvading, and the time lag between contamination and the institution of care are as important as surgical technique in determining whether or not an infection develops. 
of the procedure. Thus, it is tentatively proposed to make compensable under MAI any death or irreversible central nervous system imjury under anesthesia occurring in a patient between six months and sixty years of age undergomg any of the following procedures: tonsillectomy, cholecystectomy, hysterectomy, dilatation and curettage, repair of inguinal or hiatal hernia, abortion, sterilization, uterine suspension, venous stripping, thyroidectomy, mastectomy, and gastrectomy.

The foregomg list encompasses most of the common surgical procedures, but excludes many, such as obstetrical procedures and appendectomies, which must frequently be done on an emergency basis. It thus reflects a judgment that, simce the listed procedures are almost always scheduled in advance, the anesthesiologist will seldom be faced with the necessity for anesthetizing a rapidly deteriorating patient who cannot be adequately prepared for surgery. ${ }^{88}$ The list of covered procedures could be readily expanded if it were possible to distinguish einergency from nonemergency procedures after the fact and if an undue temptation to treat patients on an emergency basis would not be created. Clinicians' judginents would be necessary to clarify such matters and to identify additional procedures which could be safely included on the list.

One additional variable affecting the likelihood of a cardiac arrest, the competence of the surgeon, needs to be isolated in defining MAI liability of the anesthesiologist, since relieving the surgeon of all responsibility for intraoperative arrest would ignore his critical role. ${ }^{89}$ In order to preserve the surgeon's incentives and to meet the fairness criterion in the treatment of anesthesiologists, liability might be divided

88. A recent review of 286 anesthesia-related deaths found that the inadequate preparation which complicates emergency surgery was responsible for more than half the fatal outcomes. Report of Special Committee Investigating Deaths Under Anesthesia, 12 MED. J. AUSTL. 579 (1970).

89. The law of medical malpractice lras found it difficult to draw lines of demarcation between the surgeon's area of responsibility and the anesthesiologist's sphere. Traditionally, the surgeon in an operating room has been held responsible, as "captain of the ship," for all acts or omissions of attendant medical personnel, even of hospital employees, who are deemed to serve the surgeon as "borrowed servants." A. HoLDER, supra note 16, at 207-09; 1. D. Lounsell \& H. Williams, supra note 16 , TाT $16.01 \mathrm{n} .21$, $16.05 \mathrm{nn} .60 \& 67$. With advances in the technical demauds of anesthesia, the field has become specialized, and the anesthesiologist has become an important figure, medically responsible for the patient's well-being during an operatiou. Some jurisdictions' ma1practice decisions have recognized this bifurcation of responsibility, e.g., Thompson v. Lillehei, 273 F.2d 376 (8th Cir. 1959), while others have not, e.g., Mazer v. Lipschutz, 327 F.2d 42 (3d Cir. 1963), cert. denied, 385 U.S. 833 (1966) (uoting there can be only one "captain of the ship"). See also 1 D. Loursell \& H. WILLIAMS, supra note 16, If 16.06 \& nu.87-88; Note, Pennsylvania's Captain-of-the-Ship Doctrine: A MidTwentieth Century Anachronism, 71 DICK. L. REv. 432 (1967). 
between the anesthesiologist and the surgeon as follows: During induction and again during the immediate postoperative period, the anesthesiologist would be liable for fatal or debilitating arrests among patients in the age range and procedure categories specified; from the time of the initial incision until removal of the patient from the operating room, the anesthesiologist and the surgeon would each be liable for half the patient's damages cognizable under MAI. ${ }^{90}$ If liability could not be coordinated because the surgeon was not covered by MAI, the usual rules of joint and several liability would presumably govern, leaving the surgeon with the entire residual burden if his negligence should be proved.

Compensability based on patient age and procedure is justified in part by the expectation shared by laymen and pliysicians alike that death or serious ijury should not occur when the anesthesiologist and surgeon are dealing with a basically sound, young organ system and have discretion as to the timing of the procedure. Even though some young patients undergoing elective procedures present difficult problems for the anesthesiologist and surgeon and may suffer an arrest despite the best care, the seeming arbitrariness of providing compensation in such a case is not automatically a ground for rejecting the scheme but should rather be viewed as a price of achieving adnimistrative feasibility. Selection of this method of categorization does not imply fault or avoidability but merely suggests that the quality of care is potentially improvable, and the malpractice problein reducible, by adopting this technique of making physicians responsible for the outcomes they in fact achieve without regard to how or why they occurred. ${ }^{91}$ This is

90. It is understood that the operating room ritual is such that the relevant points in time are easily marked.

91. This general approach to problems in anesthesiology and surgery appears to be wholly consistent with the interests of the best elements in the medical profession in improving results, as illustrated by the SOSSUS undertakings in quality assessment. SOSSUS REPORT, supra note 42, at 191-93. The findings of the National Halothane Study, Nat'l Academy of Sciences, The National Halothane Study ch. TV-2 (1969), of substautial divergence among thirty-four hospitals in the outcoines of anesthesia no doubt reflects even wider variations in experience among individual surgeons and anesthesiologists, and reveals the potential for MAI-induced improvement in the quality of outcomes. See also SOSSUS REPORT, supra note 42, at 190-91. The SOSSUS effort, as well as an ongoing study by the National Academy of Sciences, see id. at 189, may shed further light on the existing range of quality. Such studies may also yield useful findings on how to improve surgical results, but there is good reason to anticipate that implementation of such findings would be quicker and more uriversal with MAI than without it. For a preliminary report on the SOSSUS quality study, see Study on Quality of Surgery is Unveiled, MED. WorLd NEws, Jan. 26, 1976, at 24 (forty-seven percent of adverse events and thirty-five percent of deaths were deemed preventable by surgeons reviewing the case). 
not to say, however, that additional refinements could not be made in the definition of the compensable event. ${ }^{92}$

\section{MAI's Problems AND Prospects}

\section{A. Will Deterrence Really Work?}

The arguments offered for MAI's deterrence feature and the criteria recommended for designing a selective list of compensable events both assume that medical injuries are in fact deterrable by employing financial imcentives. Nevertheless, some observers undoubtedly believe that this assumption would prove to be unwarranted or at least that the quality gains to be expected are so minimal as not to be worth the trouble. ${ }^{93}$ Though the question is one which could only be an-

92. One further possibility would be to exclude from compensation patients who have undergone other major surgery within the previous year, a circumstance highly suggestive of a fragile or deteriorating physical condition. Also, certain surgical procedures, such as operations on the heart itself, present severe risks and might readily be excluded from MAI coverage.

93. Brook, Brutoco \& Williams, supra note 6 , might take this position judging from their stance on more general issues. Although proof of the effectiveness of MAI-type deterrence in medical care is impossible, but see note 94 infra, the field of industrial accidents and workmen's compensation might be consulted for clues. The analogy is a distant one, but there is some doubt that deterrence features in workmen's compensation have reduced accidents. Thus, James Chehus found injury rates higher in states with higher benefits. Chelius, The Control of Industrial Accidents: Economic Theory and Empirical Evidence, 38 LAW \& CONTEMP. ProB. 700, 714-15 (1974). His results have been questioned, however. $\mathrm{Oi}$, On the Economics of Industrial Safety, 38 Law \& CONTEMP. PRoB. 669, 693-94 (1974). Moreover, it is not clear that the level of benefits correlates with the actual strength of incentives since insurer premium-setting practices may vary. More imiportant, if wage rates adjust to changes in benefit (risk) levels, the expected incentive effect from higher benefits might be cancelled out. Id. at 692-93. Thus, the expectation of improved safety may be misplaced. Another study produced results

consistent with the hypothesis that, across industries, work mjury rates are inversely correlated with the cost to employers of injuries. In other words, employers do seem to be responsive in their safety efforts to the cost of imjuries. It would therefore appear that, other things being equal, an injury tax would result in a reduction of the injury rate. Smith, The Feasibility of an "Injury Tax" Approach to Occupational Safety, 38 LAw \& CoNTEMP. PROB. 730, 741 (1974).

A further conclusion was that the injury tax "required to reduce these rates by even moderate amounts would have to be very large." Id. at 742.

These observations are very far from shedding hight on MAl's likely deterrent effect. For one thing, employers face trade-offs between the cost of injuries and the costs of avoiding them and will respond to incentives only if there is a net benefit to them in doing so. Providers under MAI (other than HMOs) would usually have no such cost constraint operating on them, and would be free to respond to the incentive imposed. See notes $24 \& 48$ supra. Of course, incentives might have to be stronger if effective cost constraints existed, as they do in HMOs. See Havighurst \& Tancredi 156-59, 91 94.

Another reason why industrial injury experience is a poor guide is the relatively 
swered empirically with respect to each particular class of injuries, some further explication of MAI's deterrence feature should establish that it is worth serious attention. ${ }^{94}$

Although many untoward medical events are in fact unavoidable because of the limits of scientific knowledge, nnany other outcomes are not always the result of cliance alone but might be avoided at least part of the time by the exercise of greater skill or precaution. ${ }^{95}$ If the instances of unavoidable harm could not be readily excluded from compensation by apphication of a predetermined definition, classification of the suspect outcoine as automatically compensable would still be appropriate, since some deterrence could be expected even though flawless provider performance would not eliminate all bad results. Moreover, even if a certain kind of event was technically unavoidable in every instance, its coinpensability by providers under MAI might still achieve several very useful objectives. First, it might generate more research to obtain the knowledge necessary to avert the unwanted outcome. Second, it might encourage greater circumspection about using the procedure which exposes the patient to the risk. And, third, it might stimulate greater efforts to minimize the adverse consequences once the unavoidable event occurs. It is not obvious, of course, whether the potential gains in these areas would be great enough to warrant incurring

minor importance of the matter to employers. Workmen's compensation insurance premiums average around one percent of wages, and safety is not central to the employer's overall business. On the other hand, a health care provider is likely to be highly conscious of MAI premiums and costs and of the outcomes which his patients experience.

94. The original MAI proposal developed a strong case for paying compensation in all cases of adverse reactions following blood transfusions, estimating that $\$ 133$ million in damages for post-transfusion hepatitis was potentially avoidable under appropriate incentives. Havighurst \& Tancredi 144-50, 154-55; 83-88, 90-91. See generally Calabresi \& Bass, Right Approach, Wrong Implications: A Critique of McKean on Products Liability, 38 U. CHI. L. REv. 74, 83-86 (1970); Franklin, Tort Liability and Hepatitis: An Analysis and a Proposal, 24 Stan. L. Rev. 439 (1972); Kessel, Transfused Blood, Serum Hepatitis, and The Coase Theorem, $17 \mathrm{~J}$. LAw \& EcoN. 265 (1974). The argument for deterrence in this case is very strong, and clinicians should be able to think of other areas (or particular providers) where the potential quality gains are great enough to give MAI intuitive appeal. See also note 91 supra for further suggestive evidence.

95. On the distinction between avoidable and unavoidable events, see Gorovitz \& MacIntyre, Toward a Theory of Medical Fallibility, Hastings CENTER REP. 13 (Dec. 1975). These authors, in their highly abstract but interesting article, do not address the difficulty of distinguishing avoidable and unavoidable injuries, the probable ineffectiveness and high costs associated with professional controls, or the possible value of incentives based on something more certain than the possibility of an authoritative finding of culpability or negligence. Oi, supra note 93 , at 679 , notes that many industrial accidents are not avoidable by employers; indeed contributory negligence is no defense to a workmen's compensation claim. MAI's categories will go as far as is practical in distinguishing avoidable from unavoidable events. 
the administrative costs of shifting the loss. Nevertheless, the possibility of such benefits would have to be considered for a wide range of events. Moreover, the social desirability of spreading the loss from the injured patient to society as a whole inight also point toward allowing coinpensation in a close case, ${ }^{96}$ particularly since providers' costs for such unavoidable events would probably be distributed randomly enough that they could be readily passed on in fees. ${ }^{97}$

Accident avoidance induced by MAI's deterrence feature might frequently result from action taken by parties other than the provider primarily responsible for the care giving rise to the compensable event. Thus, where a particular compensable event occurs, peer-review mechanisms might be triggered to inake a judgment on avoidability in the individual case for the purpose of determining whether the responsible provider should be advised, controlled, or disciplined in some way. Such peer oversight deterring future such events-and indeed preventive oversight not occasioned by a particular occurrence-could easily occur without any specific legal compulsion if some of the cost of each coinpensable occurrence were arranged to fall directly on a provider group which was equipped to take such action, such as a hospital inedical staff..$^{98}$ Thus, even if an individual physician were too obtuse to

96. Havighurst \& Tancredi 137-38, 78 (discussion of MAI's "social insurance" aspect, which is regarded as a by-product, not an affirmative goal).

97. But see note 106 infra.

98. Several recent proposals have suggested shifting more of the malpractice risk to the hospital as a means of providing (1) a broader base to support the compensation obligation through premiuns, which are becoming a very large expense for physicians to bear individually, and (2) a focal point for quality assurance. Roddis \& Stewart, supra note 52, at 1303; Steves, supra note 4, at 1324; VIRGINIA CoRPoration COMM'NBureau of Insurance, Medical Malpractice Insurance in Virginla: The Scope and Severity of the Problem and Alternative Solutions 79-93 (Nov. 1975). Unfortunately, such a shift might also benefit providers by improving opportunities for concealing and smoothing over situations which would otherwise generate valid claims and for presenting potential plaintiffs with a united front. Physician independence would be threatened by an increase in hospital responsibility. See, e.g., Southwick, The Hospital as an Institution-Expanding Responsibilities Change Its Relationship With the Staff Physician, 9 CaL. W.L. Rev. 429 (1973). An approach more in line with traditional hospital-doctor relations, which hospitals, insurers, or physicians could initiate with help from state insurance commissioners, would be for the medical staff of the hospital to be treated as an entity for insurance rating purposes.

MAI offers maximum flexibility in allocating responsibility between doctor and hospital. The initial question would be who is the "clieapest cost avoider"-to use Professor Guido Calabresi's phrase, G. CALABRESI, supra note 48, at 138-which means in this context only that the party in the best position to take actions to minimize costs should bear them. See notes 48, 63, 93 supra. However, the following discussion from the original proposal suggests that roughly the same preventive ineasures might be taken whichever party is selected to bear a particular risk:

We ... would expect a risk to be assigned to one [party] or the other in accordance with a judgment about which provider was best able to organize to 
respond to the financial incentive, or stood to profit enough to overlook it, other forms of deterrence would also be at work and might be felt in a strengthening of peer review in those institutions where it is now neglected.99

A frequently raised concern about introducing deterrence is that it might soinetimes work perversely, making matters worse rather than better. This would occur if treatment decisions were biased inappropriately, perhaps leading the physician to choose a treatment mode which, though it was less likely to result in a compensable event, was

reduce or eliminate it. Thus, for example, post-operative staph infections would probably be [borne by the hospital] . . . , whereas the surgeon would likely bear the primary responsibility for, say, antibiotic reactions. Although this allocation of burdens will often seem arbitrary because responsibility is shared to a large degree [footnote: For example, staph infections may prove to be more resistant to preventive measures if hospital physicians have used antibiotics indiscreetly over time.], it may prove inconsequential from a quality point of view because the hospital and the medical staff relate in ways which enable them to work together to minimize adverse outcomes. Bargaining between them would surely be initiated whichever way the responsibility was initially assigned, and it is probable that the saine preventive actions would be taken whichever party bore the initial loss .... It is an important insight that [liability] should create incentives not only for direct action, but also for initiating bargaining with others who are in a position to contribute to obtaining better outcomes. [footnote omitted] Thus, continuing to hold the surgeon responsible for the sponge count would make sense if one wished to see the surgeon reinain in control of the operating room and thought that the surgical staff would be effective in persuading the hospital to hire better counters. Havighurst \& Tancredi $139-40,80$.

The bargaining referred to is, of course, simply "desirable, quality-oriented interaction between hospitals and their inedical staffs. The obstacles to such bargaining are not costs so much as jealousies, which might yield to financial pressures." Id. at 140 n.6, 80 n.6.

The foregoing analysis borrows directly from that of Ronald Coase, Coase, The Problem of Social Cost, 3 J. LAW \& ECON. 1 (1960), and Guido Calabresi, CALABRESI, supra note 48 , at 150-52, 161-73, to the effect that, but for "transaction costs," assignment of liability to one party or the other would not affect the quality of outcomes. The striking insight is that "transaction costs" with respect to obtaining modifications in hospital-based care are not high and that therefore most of the same injury-preventing ineasures are likely to be taken whoever is held technically liable. While theoretically sound as far as it goes, this analysis leaves out the possible value of imposing potential risks on more than one actor so as to improve chances that incentives will in fact be acted on. Calabresi escapes this theoretical error by somewhat artificially including information costs in "trausaction costs," thus assuming away the limits of any one actor's knowledge of and ability to balauce risks and alternatives. Id. at 148-49. Particularly where liability insurance limits actual financial exposure and where individual providers might be either ignorant of hazards or willing to take small but unwarranted risks, risk-bearing by institutions as well as individuals, as can be readily arranged under MAI, may make especially good sense.

99. The alternative of inandating and regulating peer review efforts under PSRO or other oversight seems unreliable since going through the motions of peer review is not enough. See text accornpanying notes 37-45 supra. Wherever it is possible, alignment of financial incentives to coincide more closely with professional obhigations offers important advantages. See note 40 supra. Cf. Havighurst \& Bovbjerg, supra note 38 (on the need for incentives to stimulate peer efforts at cost control). 
not the treatment of choice under the circumstances. ${ }^{100}$ The obvious solution to this problem would be to add the undesirable outcome, perhaps even nonrecovery from the condition itself, to the list of compensable events, but this would not always be feasible. ${ }^{101}$ It is noteworthy, however, that an event which might be technically unavoidable could be justified as an addition to the list by the need to avoid biasing treatment and by the observation that the technically unavoidable result could be avoided by adopting a better mode of therapy.

Among the factors operating to prevent serious distortion of treatment decisions by MAI's imcentives are professional and ethical obligations to provide all needed and appropriate care, traditional peer-review mechanisms, and the availability of malpractice remedies for patients who are given improper treatment. ${ }^{102}$ Because the cost to the individual physician of a single compensable event would not be staggering and because the probability of its occurrence in a given case would be quite small, it seems unlikely that judgments would be significantly biased against performing professional obligations. Certainly, the distortions should be less than those introduced by the fault system, which faces the doctor with a personal near-catastrophe if he should ever be caught even slightly off base under the process-oriented rules. ${ }^{103}$ While it is clear that incentives cannot be perfectly ordered, it does not seem unrealistic to expect that MAI could bring them inore into line with professional responsibilities and quality-assurance goals. ${ }^{104}$

100. It is of course possible that in some circumstances the physician would prefer the treatment whose adverse outcome was covered under MAI, fearing the risk of a malpractice suit more.

101. Another way of minimizing the hazard would be to impose the costs on the hospital rather than the physician, relying on the latter to look out for the patients' interests. See note 98 supra.

102. Earher discussion in text accompanying notes $37-45$ supra does not hold these controls to be useless, only inadequate. MAI simply adds an additional control. Those who would rely totally on professional ethics and controls cannot deny their effectiveness in plugging unavoidable gaps in MAI incentives.

103. An example appeared at a recent seminar: If no other blood is available, should a nurse-anesthetist use twenty-two day old blood, i.e. blood which is one day past the expiration date on its label? The answer from the medical-legal experts was "no," but all agreed that under MAI it would be reasonable and good medicine to do so. N.C. Society of Anesthesiologists, Fall Seminar, Charlotte, N.C., Nov. 15, 1975.

104. No adverse outcome of surgery was omitted from the hist of compensable events accompanying notes 71-85 supra out of fear that needed surgery would be discouraged by inclusion of such an outcome. Neither was any attempt made to guarantee compensation for the adverse consequences of not operating. Nevertheless, it is believed that treatment decisions would not be unduly biased. For one thing, a malpractice lawsuit could be filed for serious neglect of the surgical option. More important, there is strong evidence that surgeons' incentives are at present excessively weighted toward performing 
A possibly worrisome example of the bias which MAI might introduce is the possibility that high-risk patients miglit be actively avoided by providers under an MAI system. Of course, abandonment of a patient is itself a tort ${ }^{105}$ and would remain so with MAI. Further, wherever refusals to accept a ligh-risk patient might occur because the patient's predisposition was apparent prior to the mitiation of treatment, it should be possible to define the compensable event in such a way as to exclude those patients who present sucli obviously increased risks. This course sliould not be adopted too quickly, lowever, because MAI could appropriately be designed to encourage the physician to consider the patient's predisposition as a factor in his decision to treat. Moreover, referral to another provider is available as an alternative ineans of escaping a difficult patient. Sucl referrals should probably be encouraged by the MAI system, simce anotlier provider may be inore competent, more specialized, or better equipped to handle the problem. This would presumably be the case with referrals to a major medical center, and presumably the referral physician would be in a position to charge higher fees and therefore to face the greater risks which difficult cases may entail. ${ }^{106}$

Although it is difficult to be totally confident that MAI's deterrence feature would be finely tuned to achieving quality goals, there

surgery, without adequate regard for its high costs and attendant risks. See Bunker, Surgical Manpower: A Comparison of Operations and Surgeons in the United States and in England and Wales, 282 NEw ENG. J. MED. 135 (1970); Lewis, Variations in the Incidence of Surgery, 281 New ENG. J. MED. 881 (1969). Making surgery's adverse results compensable under MAI might succeed in restoring some balance to surgeons' decisions on the need for radical neasures. Again, clinicians' judgments might suggest areas where further attention to these problems would be appropriate.

105. 1 D. LouISELL \& H. WIILIAMS, supra note 16, If 8.02, at 192.

106. Irrespective of their competence, some providers are more likely than others to experience particular bad outcomes because of the nature of their practice or their clientele. Higl-risk plyysicians would include in particular those in teaching institutions who treat more difficult cases, many on referral from practitioners having less specialized skills and perhaps, under MAI, a justifiable apprehension of a coinpensable outcome. MAI should not be pernitted to cause sucl high-risk physicians' net incoines to suffer to the point that people would be discouraged from accepting hard cases within their competence or from practicing in such settings.

The best answer to this possible problem is that such skilled physicians can, do, and should charge higler fees, thus not only passing the inherent risks on to the public but also usefully rationimg, through higher prices, patients' access to physicians with superior skills. Because sucl physicians are all similarly situated, none would be at a competitive disadvantage unless he was experiencing a higher-than-normal incidence of claims for the category of patients treated. See Havighurst \& Tancredi 151-52, 88-89. Although it is important to guard against unfairness in the treatment of providers, there does not appear to be essential unfairness here. Of course, governmental imposition of fee schedules could create unfairness if allowances were not made for differential exposure under MAI. 
is nothing inherent in the idea which foredooms it to failure, and the flexibility of the MAI mechanism is such that most objections based on equity and efficiency considerations can seemingly be overconie, at least as a theoretical matter. What is needed for a preliminary assessment of MAI's practical effect is, first, active participation by willing clinicians in the specification of compensable events, and, second, a trial of their list in the real world. Although an experiment of reasonable scope and duration could probably not reliably reveal the effectiveness of MAI in improving the quality of care, it could probably be established that MAI would not do affirmative harm. If so, MAI might appropriately be established even though there was no fimal assurance of its capacity to improve the quality of care significantly. Since MAI is almost certain to be an improvement over the present systen in other respects, any quality gains it might achieve in addition could be regarded as a bonus. The added costs of financing MAI in such a way as to preserve incentives would not be great enough to warrant sacrificing the deterrence element unless it had been conclusively shown to be ineffective.

\section{B. MAI's Ultimate Scope}

The value of MAI as a replacement for the fault systenu depends in large part on its coverage. Thus, it would probably have appeal for providers and policy makers only if a substantial proportion of the malpractice claims currently being filed against providers would be obviated or if the dollar costs of the fault system would be drainatically reduced. A judgment on this matter can be made only after a definitive hist of compensable events is established and compared to a sample of claims. ${ }^{107}$

107. In an effort to appraise the extent to which an MAI scheme covering the events kisted above would obviate malpractice claims, the claims file sampled in Rudov, Myers \& Mirabella, Medical Malpractice Insurance Claims Files Closed in 1970, in MEDICAL MALPRACTICE REPORT Appendix 1, was consulted with the assistance of the Urban Research Center, University of Wisconsin (Milwaukee). Although the data available proved too unspecific as to imury and diagnosis to allow reliable matching of specific claims files against the list, it was estimated that sixty-one percent of the dollars paid out in 1970 on account of claims against anesthesiologists were paid in cases involving death or irreversible central nervous system damage to patients between one and fiftynine years of age undergoing nonemergency surgery and therefore seemingly falling within one of the compensable categories established. Although these payouts disposed of only about twenty percent of the claims agaimst anesthesiologists which actually resulted in some payment, many of the remaining claims and payments would undoubtcdly be obviated by the additional category of compensable events encompassing dental and peripheral nerve injuries. Unfortunately, the lack of detailed information on diagnosis, treatment, and injury made it impossible to identify new categories of events whose addition to the list would obviate additional claims.

It is obvious that MAI development requires highly detailed and readily disaggre- 
The appraisal of MAI's prospects must be done on a specialtyby-specialty basis since its feasibility is likely to be greater in some areas than in others. Thus, because of their definitive character and apparent avoidability, hospital accidents, surgical mishaps, adverse consequences of anesthesia, and poor results of orthopedic care lend themselves to dehineation as compensable events; much the same reasons account for the heavy imcilence of malpractice claims for these same injuries, which suggests in turn a reasonable prospect that MAI can alleviate the malpractice crisis in these hard-hit areas. On the other hand, the diagnostic errors in internal medicine are hard to assess without a full inquiry of the kind provided in the fault system. Thus, internal medicine, fraught with uncertainty and "judgment calls," would be less likely to benefit from MAI; for similar reasons, internists have been less beset by malpractice suits than have the other specialties. ${ }^{108}$ It thus appears that MAI will work best in precisely those areas where it is most needed as a remedy for the malpractice situation.

Another question concerning MAI's scope and ability to solve the malpractice-suit problein is whether the list of compensable outcomes, in focusing on definitive, relatively avoidable events, will in fact avoid major administrative costs. To the extent that only the "easy" malpractice claims are eliminated, the cases involving high administrative costs may still remain in the fault system, and attempts to expand the list to cover more equivocal cases may generate litigation over the fuzzier boundary lines.

Until sophisticated clinicians turn an open mind to these issues, firm answers will not be forthcoming. Without careful evaluation of MAI on its own terms, clinicians' and others' opinions on MAI's feasibility may reflect only their uninformed reactions to the idea of deterrence and increased provider accountability.

\section{Costs}

Probably the main constraint on the growth of MAI to encompass nearly all malpractice claims is the potential overall cost of the system.

gatable data on malpractice claims, including fairly precise information on (1) diagnosis, including complications; (2) treatmeut; (3) injury, with specificity as to nature, seriousness, and damages paid, if any; (4) alleged negligence, so that claims which are not specific to the particular procedure (e.g., failure to diagnose, failure to obtain informed consent, foreign bodies, abandonment, and falls) can be broken out; and (5) physician and patient characteristics. None of the data collectiou efforts to date has sought detailed medical information of the type needed to appraise, refine, and extend MAI's impact.

108. Id. at 15-16. 
Any research effort would quickly focus on the incidence of each compensable event and on the total cost which MAI coverage of that event would entail. If the greater number of payments would more than absorb the savings from lower administrative costs and froin smaller awards, MAI would appear to threaten to imcrease the cost of medical care, perhaps substantially. Of course, this is deceptive, since the costs are not new ones but are already being incurred under the present system even though they are to a large extent left where they fall-frequently on the injured patient. Also, the current incidence of the outcomes to be made compensable under MAI is a poor indicator of potential costs, simce any strengthening of incentives for improved outcomes should reduce the incidence of bad results and improve the system's overall performance. Thus, acceptance of costs under MAI may avoid greater costs elsewhere and produce a true social saving. ${ }^{109}$

The original MAI proposal discussed the possibility of providing a limited subsidy to the MAI fund in order to keep the insurance premiums manageable, perhaps near zero for providers with good experience. Indeed, the desired incentive for good provider performance could, with a sufficient subsidy, just as appropriately take the form of a bonus for good results as a levy for bad experience. Subsidy possibilities should certainly be considered as a means of assuring that the premium cost would not force providers to bear collectively, even as a conduit, the entire financial burden of the many ills which MAI might cover.

The origimal MAI proposal also contemplated reimbursements by the MAI fund to collateral sources of payments for medical expenses and wage losses. This recommendation contrasts sharply with other proposals, which would reduce awards by the amount of such payments received, thus effecting major dollar savings.110 From a social standpoint, of course, such savings are only apparent and not real, since costs

109. On the prospective dollar costs and health benefits of classifying hepatitis following blood transfusions as compensable, see Havighurst \& Tancredi 154-55, 90-91.

110. E.g., Moceri \& Messina, The Collateral Source Rule in Personal Injury Litigation, 7 GoNZAGA L. REv. 310 (1972); O'Connell, No-Fault Insurance for Injuries Arising from Medical Treatment: A Proposal for Elective Coverage, 24 EMORY L.J. 21, 35-36 (1975); Schwartz, The Collateral-Source Rule, 41 BostoN U.L. REv. 348 (1961); Note, Unreason in the Law of Damages: The Collateral Source Rule, 77 HARv. L. REv. 741 (1964). Some observers have suggested that adoption of a national health insurance plan would go a long way toward solving the malpractice problem. E.g., Annas, Medical Malpractice Litigation Under National Health Insurance: Essential or Expendable?, 1975 DUKE L.J. 1335. This would indeed obviate many suits and permit reduction of awards by the amount of covered expenses, but would simply hide the cost of poor medical results. 
to the MAI system would be exactly offset by savings to health insurers and other collateral sources. This fact may well be lost sight of, however, in formulating both governmental policy and policies of private insurance. ${ }^{111}$ Nevertheless, the principles of MAI almost certainly require that all the costs of covered imjuries pass through its accounting mechanism in order that incentives reflecting the system's costs will not be distorted by the fortuitous presence or absence of collateral sources.

One way of offsetting the seemingly higher dollar costs of MAI would be by drawing some of the suggested subsidies for the MAI fund from the various collateral sources. These third-party payers for health care and reinbursers of lost wages would stand to benefit from MAI reimbursements to thein as collateral sources, froin the reduced incidence of defensive medicine under MAI, ${ }^{112}$ and from the improvements induced by MAI in the quality of care generally. It would seem easy enough to offer MAI reimbursements only to those collateral sources which paid "dues" equal to, say, eighty percent of expected reimbursements. Larger subsidies could also be justified.

\section{Prospects}

The prospects for MAI are problematical. It is possible, though the facts are still not clear, that the scope of MAI would have to be quite broad in order for it to make a major contribution to solving the malpractice problem. ${ }^{113}$ Such broad scope would in turn entail the substantial dollar costs of socializing the consequences of many mjuries which are now borne privately, and it is quite possible that, to decisionmakers in governinent and the health imdustry, these costs will not seem worth incurring as an added overt cost of health care even if they represent a inuch better bargain for the public. ${ }^{114}$ Moreover, such deci-

111. See O'Connell, No-Fault Liability by Contract for Doctors, Manufacturers, Retailers and Others, 632 Iss. L.J. 531, 532-33 (1975); O'Connell, An Elective No-Fault Liability Statute, 628 INs. L.J. 261, 264, 278 (1975).

112. MAI would encourage expenditures to improve outcomes but would obviate unproductive expenditures now allegedly incurred by physicians concerned about malpractice suits. See note 24 supra and text accompanying note 5 supra. PSROs may be able to impose some restraint on expenditures which were not cost-justified. See notes 14, 48, 93 supra.

113. For an opinion that MAI would be too narrowly conceived to solve much of the problem, see Note, Comparative Approaches, supra note 19, at 1153-54.

114. What is involved, of course, is a kind of compulsory insurance which, while far better than the present kind (which devotes most of the premiums to contesting claims on technically complex grounds unrelated to the fact of injury), would be somewhat more expensive because of the greatly expanded coverage. Health care costs are politically visible, and anything raising them is likely to be unpopular. Although MAI would only appear to be a new cost of health care, it would face difficulty if added expense were entailed. Courts imposing strict liability in tort face no such constraint but lack 
sion-makers may fail to attribute any positive value to MAI's qualityassurance feature as a further benefit which might justify the appearance of higher costs, preferring instead the establishment of controls maintained by governmental or professional overseers or by a partnership thereof, such as the PSRO program. Narrowness of focus, a preference for incremental as opposed to drastic change, and commitment to pohitical solutions are characteristic of the policy-making process, so that even a disaster like the law of medical malpractice is more likely, in the normal course of things, to be smoothed over than to be made the occasion for a new departure.

For the foregoing reasons, the MAI idea would probably have little chance even for serious study were it not for the appearance of another proposal for a no-fault compensation system which bids fair to displace the fault system, at least in part, without any legislative action at all. Because this proposal, for what is called "elective no-fault" insurance, ${ }^{115}$ rehes heavily on selective specification of compensable events in soinewhat the same inanner as MAI, it is likely to induce the same kinds of evaluation and research whicli are required to give MAI content and concreteness. Out of the public and private examination of the no-fault notion which the elective no-fault idea is certain to stimulate may energe a set of realistic policy options which are different from those now apparent, and, in this new environment, MAI may turn out to have a future. A comparison of "elective no-fault" and MAI will set the stage for a concluding speculation on MAI's prospects.

\section{A Comparison of MAI aNd "Elective No-FaulT"}

Professor Jeffrey O'Connell has proposed "elective no-fault" insurance as a means whereby providers of medical care can escape some of their current malpractice burdens by voluntarily granting their patients limited "no-fault" rights in exchange for the patients' surrender of their right to sue in tort over an outcome made compensable on a no-fault basis. According to O'Connell, the terms of this exchange might be either dictated by providers and made binding on patients under legislation which he has proposed ${ }^{116}$ or accomplished without legislation by contracts entered into by providers with their patients. ${ }^{117}$ The purpose, much as with MAI, would be to use funds which are now swallowed up in extravagant awards and the adjudication of fault issues

the capability to design an MAI scheme with any limits. Id. at 1157. But cf. Note, Continuing the Common Law Response to the New Industrial State: The Extension of Enterprise Liability to Consumer Services, 22 U.C.L.A.L. Rev. 401, 428 n.121 (1974).

115. See text accompanying notes 123 et seq. infra.

116. O'Connell, An Elective No-Fault Liability Statute, supra note 111.

117. O'Connell, No-Fault Liability by Contract, supra note 111. 
to pay more claimants smaller amounts automatically. ${ }^{118}$ Professor O'Connell's assumption is that there is enough money to be saved by removing the necessity for fault-finding, by reducing payouts to the extent of payments from collateral sources, ${ }^{119}$ and by denying recovery for pain and suffering ${ }^{120}$ to make such insurance an attractive alternative for both patients and providers, ${ }^{121}$ particularly in view of the additional rehef provided froin the unpleasantness, uncertainty, and delay of malpractice lawsuits.

The elective no-fault model has great appeal. In inviting private transactions to bypass malpractice mechanisms, ${ }^{122}$ it obviates the need for legislative reforin and calls attention to the opportunity for achieving more far-reaching change than is likely to be wrought through legislatures responding to organized interest groups. The logic of private action to squeeze out the middlemen, primarily the lawyers, is powerful, and it is reasonable to expect that the potential ganis will induce action on this front.

\section{A. Deterrence Under Elective No-Fault}

Although the O'Connell scheme may represent a modest beginning toward a kind of MAI, it is not explicit on the inatter of incen-

118. O'Connell, supra note 110 , at 35 . The premise is the same as under automobile no-fault-namely that no more and probably less cost will be experienced than under the fault system.

119. Id. See notes 110-11 supra and accompanying text.

120. Id. at 34-35. See Havighurst \& Tancredi 128-29, 72 (proposing limited pain and suffering awards).

121. It is possible that $O^{\prime}$ Connell exaggerates the cost savings which his system would yield: (1) Patients with steady or higher incomes would be more likely to have protection from collateral sources, which would reduce their entitlements under the no-fault plan; they would therefore refuse the option tendered, preserving the hazard of large awards based on wage loss. (2) The no-fault policy is more likely to cover outcomes reflecting obvious and easily provable negligence than to cover more questionable outcomes, see note 130 infra, which are precisely the ones which occasion most of the major adıninistrative expenses which $O^{\prime}$ Connell hopes to save. (3) A trade-off clearly exists between the liberality of the no-fault scheme and prospective claimants' propensity to litigate to escape its coverage and qualify for a tort remedy; O'Connell's scheme, by allowing only actual out-of-pocket losses, would induce many skirmishes at the borderlines, unless compensable events were very sharply defined. Of course, a more liberal plan might increase insurer and provider resistance to payment, but this could be dealt with by requiring the insurer to bear the successful clannant's costs of litigating coverage questions. See Havighurst \& Tancredi 132, 74.

122. Dean Richard Rosett of the University of Chicago Graduate School of Business supports a variant of the O'Connell plan, suggesting that a physician might offer his patients a choice between the present system and a no-fault alternative at a higher or lower price. Rosett, The Medical Malpractice Insurance Crisis, Medical Malpractice Crisis Conference (U. of Md. Law School, Nov. 21-22, 1975). The implied belief that doctors would actively seck to accommodate their patients seems unduly optimistic for reasons stated in notes 127 \& 130 infra. 
tives, ${ }^{123}$ and the insurance conteinplated might well not feature the experience rating or cost-sharing arrangements contemplated in the MAI model. Conceivably, insurers would find it in their interest to adopt experience rating or to include provider cost-sharing provisions in their policies, but this cannot be counted upon in a heavily regulated, indifferently competitive inarket.124 Although providers with better experience might press for price concessions, the organized medical interests which would be engaged in developing the no-fault policy ${ }^{125}$ would strongly prefer that costs be shared in a way facilitating their automatic pass-throughr to patients. Moreover, it is not likely that patients, in contracting privately, would attach particular value to designing an imsurance arrangement which preserves providers' quality-inducing incentives. $^{126}$ Finally, if the insurance was designed without specific attention to the avoidability of the covered injuries, incentive pricing of it would seem more unreasonable than under MAI.

For the foregoing reasons, introduction of elective no-fault could easily cost society its only opportumity for designing a deterrence feature into the new system for compensating for medical injuries. This result is not inevitable, however, and insurance regulation could well stimulate attention to the design and pricing of elective no-fault insurance which would achieve nany of the goals of MAI.

\section{B. Compensable Events Under Elective No-Fault}

Although the O'Connell plan involves specifying compensable events in much the same manner as MAI, the list of medical outcomes compensable under it would be shorter than under an MAI scheme developed by administrative means pursuant to a statutory inandate. Providers responding to O'Connell's call would have no reason voluntarily

123. Professor O'Connell himself has attached no importance to this aspect, though he would probably not oppose the introduction of an incentive feature. His view of the malpractice problem is similar to his view of automobile no-fault, however, where incentives seemed much less likely to work. For a guide to O'Connell's general orientation, see J. O'Connell \& R. Henderson, Tort Law, No-Fault and Beyond (1975), which devotes only limited coverage to deterrence possibilities. E.g., id. at 624-28.

124. See text accoinpanying notes 51-55 supra.

125. See note 127 infra.

126. Although patients might be well advised to msist that incentive features be preserved, their ignorance and traditional trust of physicians would probably result in their acceptance of the insurance protection offered without regard to how it was financed and what it did to provider imcentives. In these circumstances it would not be mcorrect to characterize quality assurance as an external benefit potentially flowing from the MAI model-that is, as a public good which the contracting private parties themselves have no incentive or opportunity to realize im structuring a program of no-fault benefits to replace fault-based liability, thereby destroying whatever deterrence value the latter may have. 
to purchase coverage for avoidable outcomes which, though unfavorable from the patient's point of view, become the subject of malpractice claims in only a small percentage of cases-possibly because any negligence contributing to them is difficult to discover or to prove. ${ }^{127}$ Thus, elective no-fault, having its baseline in the existing system and being designed by providers primarily for their own benefit, would be viable only to the extent that physicians perceived a benefit to themselves, in terms of cost and avoidance of unpleasantness, in establishing compensable categories.

Although Professor O'Connell has yet to be specific about the coverage contemplated, he has observed the necessity for broadening the class of compensable events somewhat beyond those readily covered in the fault system in order that some mutuality of benefit between patients and doctors appear when the inevitable legal questions are raised concerning either the constitutionality of any legislation $^{128}$ or the enforceability of the contracts employed. ${ }^{129}$ It is indeed probable that patients must appear to receive a reasonable quid pro quo if legal challenges to elective no-fault are to be resisted, but provider dictation of the terms of an exchange would still produce a greater reduction in patients' malpractice riglits and a smaller expansion of their no-fault rights than would a bargaining process in which consumers participated with equal bargaining power and capacity. ${ }^{130}$

127. Professor O'Connell contemplates that providers and insurers will jointly design the insurance coverage. Although at some points, e.g., O'Connell, No-Fault Liability by Contract, supra note 111, at 532-33; O'Connell, An Elective No-Fault Liability Statute, supra note 111, at 264-66, 270-71, he appears to suggest that individual providers could design the coverage they wished to offer (suggesting that competition anong providers to offer consumers the most attractive combinations of rights might ensue), this is manifestly impossible given the exigencies of insurance, which require uniform contracts and large groups for rating purposes. The more likely scenario, which O'Connell probably also visualizes, is the development of uniform insurance contracts by specialty societies, to be offered to patients on a take-it-or-leave-it basis. The probability that such contracts of adhesion will be employed is strengthened by the understandable reluctance of providers to haggle with patients over matters raising the spectre of untoward events which might occur in the process of treatment.

128. J. O'ConNell, ENDING Insult to INJuRY 204-31 (1975); O'Connell, An Elective No-Fault Liability Statute, supra note 111, at 262-63.

129. O'Connell, No-Fault Liability by Contract, supra note 111, at 540-42; O'Connell, An Elective No-Fault Liability Statute, supra note 111, at 204-31.

130. Possible additions to the list of compensable events fall into three categories: (1) those additions which would benefit doctors and hurt patients (e.g., an outcome now readily discovered and almost automatically compensable with an allowance for pain and suffering, which under MAI would be compensated at a lower rate without significant administrative savings); (2) those additions which would benefit both doctor and patient (e.g., an outcome now occasioning enough administrative costs that all events could be coinpensated at a cost hardly greater than the old system entailed); and (3) those additions which would benefit patients only (e.g., an outcome previously com- 
Legal doctrines designed to prevent unconscionable contracts, while perhaps effective in preventing provider overreaching which makes consumers worse off than they are at present, are unlikely to help patients receive all of the benefits to which they might be deemed entitled. Two serious issues with "elective no-fault" thus emerge: (1) whether the fault system should be displaced only to the extent that it suits providers to displace it and (2) whether the possibly substantial benefits to be derived from partially displacing the fault system should accrue only to providers or should be allocated nore equitably between providers and patients.

\section{How MAI Legislation Could Improve Upon Elective No-Fault}

The problems with elective no-fault could be overcome by legislation doing nore than simply authorizing providers to adopt, and either offer to or impose on patients, a no-fault plan of their own devising. Such legislation would be more than a simple enabling act blessing private no-fault arrangements, and would establish many of the plan's details while leaving delineation of compensable events to an administrative mechanism. Of course, this administrative process might yield results no different than those under provider-designed elective no-fault if the mechanism were itself dominated by providers, but specific provision would undoubtedly be made for obtaining knowledgeable representation of consumer interests. ${ }^{131}$ An exchange of malpractice and no-fault rights between providers and patients would be more likely to produce an equitable outcome if it took place through a political bargaining process than if its terms were dictated by providers. ${ }^{132}$ Also,

pensated so rarely that significantly increased costs would result under elective no-fault). Physicians would undoubtedly be glad to accept no-fault liability for items in categories (1) and (2) but would not add items in category (3) unless they were convinced it was necessary to do so to overcome legal challenges. See text accompanying notes 128-29 supra. Whether they would actually be harmed by further additions is not clear since patients might willingly pay higher fees for the increased protection. Nevertheless, there are many reasons-fee schedules inhibiting fee increases, the risk of government displeasure, reluctance to enter the business of selling a kind of insurance and explaining the hazards it protects against, and so forth-why providers would seek to avoid incurring increased costs and would offer only no-fault coverage designed for their own benefit. Medical traditions being what they are-seriously anticompetitive-, competition would be unlikely to stimulate a range of choice even if the exigencies of the insurance busmess did not largely preclude experimentation and product differentiation. Instead, organized professioual groups, in designing the coverage, will take account of their members' interests alone.

131. The original MAI proposal seened to promise more professional influence in delineating compensable events than now seems appropriate. See Havighurst \& Tancredi $163-64,97$.

132. See note 130 supra. 
the prospects for subsequently expanding the list to achieve new quality-assurance objectives would be substantially enhanced.

Reliance on the administrative process to develop the MAI option would also allow careful attention to all the problems of introducing appropriate incentive features. A statutory mandate to pursue deterrence would stimulate the needed attention to this aspect of the no-fault concept, but if the agency found, on the basis of controlled studies and other evidence, that the deterrence goal was chimerical, it could lay that aspect to rest and still maintain a no-fault scheme for the sake of its value as a less costly alternative to the fault system. Moreover, with the proper inandate, the agency could also elect to pursue quality objectives by administrative means, perhaps by flagging coinpensable outcomes for peer investigation to detect specific quality failures warranting remedial action. It thus seems clear that the nofault model could be establislied legislatively without positive evidence that MAI's incentive feature would improve the quality of care at a reasonable cost. All that is required is a legislative mandate to an administrative agency to develop and make available a no-fault option, to design into the scheme such incentive features as it found workable, and to adopt other quality-assurance mechanisms where deterrence features proved either wholly unworkable or madequate in and of themselves to achieve quality goals.

Although MAI should certainly have an elective feature of its own, ${ }^{133}$ it should not, im contrast to the O'Cormell proposal, be neutral

133. Presumably providers would opt in or out, and their decisions would bind their patients. This is the approach of the Kennedy-Inouye bill, S. 215, 94th Cong., 1st Sess. (1975), and it would allow consumers to express their preferences through their choice of provider rather than in negotiations, as Dean Rosett contemplates. See note 122 supra.

If an MAI plan with rehable quality-assurance incentives were ultimately adopted, certain special inducements for provider participation, in addition to curtailmeut of their exposure to fault-based liability, might be deeined appropriate. For example, the following measures beneficial to providers participating under MAI might be helpful not only as a stimulus to MAI participation but also as steps in the direction of a policy of primary reliance on outcomes measures of quality rather than on expensive process controls and restrictive input specifications: (1) A provider electing MAI could be given some rehief from licensure restrictions on the use of nonpliysician manpower. See U.S. Dep'T of Health, Education aNd Welfare, Developments In Health MaNpower LICENSURE 47-49 (DHEW Pub. No. (HRA) 74-3101) (June 1973); U.S. DEP'T OF Health, Education \& Welfare, Report on Licensure and Related Health PersonNel Credentraling 65-70 (DHEW Pub. No. (HSM) 72-11) (June 1971). (2) Physician relicensure and continuing education requirements might be applied only to nonparticipants in MAI. But cf. S. 215, 94th Cong., 1st Sess. (1975) (looks the other way, imposing such requirements only on participants in a no-fault scheme lacking qualityassurance incentive). (3) Physicians and hospitals subscribing to MAI could be exempted in whole or in part from quality regulation by PSROs, and health maintenance 
on quality issues, and, if at all possible, it should represent, in contrast to the Kennedy-Inouye bill, a new departure in quality assurance away from costly and unproven governmental controls. Its coverage and attractiveness to providers should not be governed solely by the scope and severity of the malpractice threat as perceived by individual providers but should instead be dictated in substantial part by affirmative quality concerns and attention to patients' interests. The fault system's defects should not be allowed to infect MAI-to rule it "from the grave," as it were ${ }^{134}$-or to limit its ability to perform a reasonably coinprehensive quality-assurance function in areas entrusted to its care.

Despite the foregoing reservations about elective no-fault, which suggest that it would fall short of achieving all that the original MAI proposal held possible, the $\mathrm{O}^{\prime}$ Connell proposal has great force as well as the great advantages of being non-legislative and somewhat incremental in its impact and of bypassing numerous obstacles to adoption of the no-fault concept. Although its widespread adoption might foreclose later attempts to reintroduce incentive features, for the immediate future the tasks involved in developing the O'Connell plannamely delineating compensable events and testing their mipact on inalpractice claims and costs-are very nuch in keeping with advancing the MAI proposal. There is every reason to believe that elective no-fault will be attractive enough to stimulate prompt investment in such research and that some study of MAI will be included in that effort. The outcome should be a much more solid basis for considering the inerits of both proposals.

\section{CONCLUSION}

If present legislative endeavors do not reduce the malpractice-suit

organizations under MAI could be relieved of PSRO oversight. See Havighurst \& Bovbjerg, supra note 38; Bovbjerg, supra note 16. But see notes 48 \& 93 supra. (4) Hospitals under MAI could be allowed to qualify automatically (or at least more easily) for state licensure, participation under Medicare, and JCAH accreditation. (5) MAI participation could be made more attractive by not cutting back too arbitrarily on plaintiffs' rights under traditional principles.

MAI might prove popular with providers for other reasons besides the foregoing special inducements. Because MAI might be designed, as in the original nnodel, Havighurst \& Tancredi $139-40,79-80$, to shift to the lospital certain risks normally borne by the physician, he would escape these risks altogether by participating; by the saine token, his exposure as a joint tort feasor would be increased if other participants' liability was limited under MAI and his was not. Moreover, a subsidy to the MAI fund, see text at 109 supra, could improve the comparative cost picture substantially. Finally, if the program was properly designed, patients would probably be attracted to it since it would improve their protection overall, and doctors would therefore have some incentive to offer it as an accommodation to their patients.

134. See Blum \& Kalven, Ceilings, Costs, and Compulsion in Auto Compensation Legislation, 1973 UtAH L. REV. 341, 376. 
problem to manageable proportions, pressure for a no-fault compensation system for medical accidents will continue to grow. ${ }^{135}$ The cost of compensating patients for all iatrogenic injuries could well be prohibitive, however, even if it were limited to reimbursing only out-of-pocket costs, if national health insurance absorbed most of the medical expenses, and if the administrative costs about which Professor Keeton has warned were reduced by a substantial deductible. There might therefore be a strong temptation to adopt no-fault insurance on a more selective basis, using the technique, employed under both MAI and Professor O'Connell's elective no-fault scheme, of specifying a limited set of compensable events in advance. Once the principle of selectivity was adopted, it seems probable that emphasis would be placed on providing compensation in those categories of cases which are most likely to generate malpractice claims--that is, those in which the regrettable outcome is most frequently avoidable. Because the impetus for the entire effort would be to substitute no-fault rights for common-law rights, the hist of compensable events would surely appear to the layman to represent a catalog of the system's failures, and it is at least questionable whether the public would be willing to pick up such an itemized bill. In these circumstances, it seems likely that pressure would emerge for preserving some accountability for these costs on the part of those providers whose patients suffer the compensable adverse results. This scenario of course calls for MAI then to enter in shining armor, to slay the malpractice dragon, and to establish in the land a regime based on reason, provider accountability, and compassion for the victims of medical accidents.

Properly understood, MAI is not a radical measure, and it does indeed hold out a hope for avoiding much contentiousness and cost, which are currently by-products of malpractice hitigation and which would also attend an effective regulatory scheme designed to make providers accountable by regulatory means and to alter the behavior of a significant number of them in material respects. In these circumstances, it is reasonable to expect the health care system to devote some resources and thoughtful consideration to converting MAI's promising theory into practical reality. Only a limited amount of study would be necessary to qualify MAI for adoption by a forward-looking state legislature, with a direction to an administrative agency to establish the scheme in such a way as to seek a major reduction of both malpractice claims and, through deterrence, medical imjuries.

135. E.g., Report of the Special Advisory Panel on Medical Malpractice, STATE OF NEW YORK 53-63 (Jan. 1976). 